\title{
Feeling useless: the effect of unemployment on mental health in the Great Recession
}

\author{
Lídia Farré ${ }^{*}$, Francesco Fasani ${ }^{2}$ and Hannes Mueller ${ }^{3}$
}

\author{
*Correspondence: \\ lidia.farre@gmail.com \\ 'Universitat de Barcelona, IAE (CSIC), \\ MOVE and IZA, Barcelona, Spain \\ Full list of author information is \\ available at the end of the article
}

\begin{abstract}
This article documents a strong connection between unemployment and mental distress using data from the Spanish National Health Survey. We exploit the collapse of the construction sector to identify the causal effect of job losses in different segments of the Spanish labor market. Our results suggest that an increase of the unemployment rate by 10 percentage points due to the breakdown in construction raised reported poor health and mental disorders in the affected population by 3 percentage points, respectively. We argue that the size of this effect responds to the fact that the construction sector was at the center of the economic recession. As a result, workers exposed to the negative labor demand shock faced very low chances of re-entering employment. We show that this led to long unemployment spells, stress, hopelessness, and feelings of uselessness. These effects point towards a potential channel for unemployment hysteresis.
\end{abstract}

JEL Classification: 110, J60, C26

Keywords: Mental health, Great Recession, Unemployment, Hysteresis

\section{Introduction}

The Great Economic Recession which started with a global financial crisis in 2007 had severe effects on the Spanish labor market (Bentolila et al. 2017). In particular, the unemployment rate followed a dramatic path, increasing from about $8 \%$ in 2007 to more than $25 \%$ in 2011 . The construction sector was hit the hardest: more than $60 \%$ of all jobs in this sector were lost by $2013 .{ }^{1}$ As a result, employment in this sector decreased from $13 \%$ of total employment in 2007 to less than 6\% in 2013. The repercussions of the crisis can still be felt today. According to EuroStat, long-term unemployment in Spain is falling but stays high: it was at $7.1 \%$ in the fourth quarter of 2017, approximately twice the EU15 average for the same period.

This article shows that the unemployment spells suffered by workers in Spain during the Great Recession led to a drastic relative deterioration of their mental health. Figure 1 presents measures of mental well-being by employment status taken from the Spanish National Health Surveys of 2006 and 2011. Unemployed workers are clearly in worse health than their employed counterparts. They are less self-confident, appear overwhelmed by their problems, and report markedly higher diagnosed mental disorders.

(c) The Author(s). 2018 Open Access This article is distributed under the terms of the Creative Commons Attribution 4.0 International License (http://creativecommons.org/licenses/by/4.0/), which permits unrestricted use, distribution, and reproduction in any medium, provided you give appropriate credit to the original author(s) and the source, provide a link to the Creative Commons license, and indicate if changes were made. 


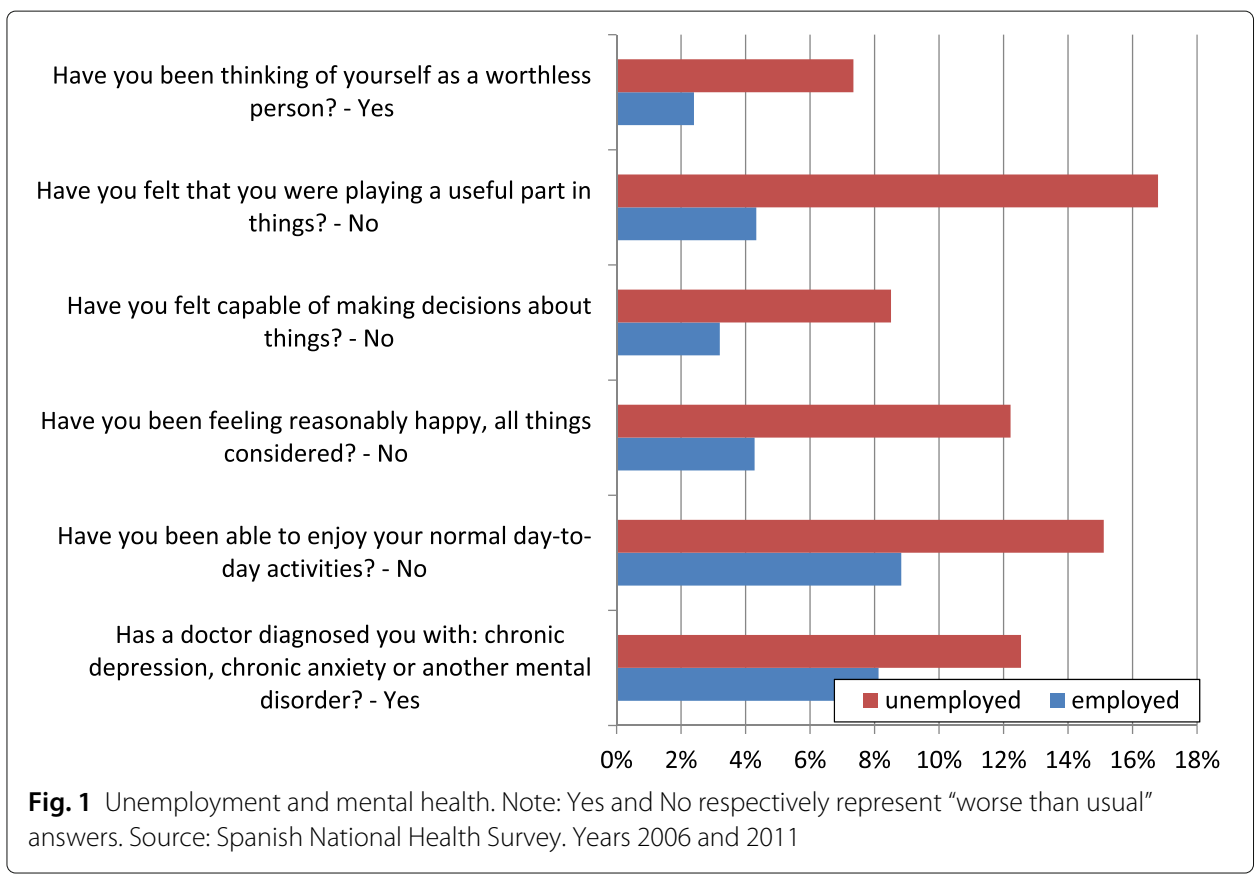

However, these are simple correlations and are, therefore, uninformative about the underlying direction of causality. Mental disorders such as depression or chronic anxiety could be the result of unemployment, but it could also be that poor mental health leads to job loss or the inability to find employment.

The relationship between unemployment and health has been extensively explored. Alternative identification strategies, data sets, and labor market conditions have produced a vast array of results. These range from very large effects on mortality after job displacement (50-100\% increases) as in Sullivan and von Wachter (2009), Eliason and Storrie (2009a) or Browning and Heinesen (2012) to relatively small ones (10-15\% increases) as in Rege et al. (2009). The variance of the estimated effects on other-less severe-health and mental health outcomes is even larger, both within and across outcomes. Remarkably, several excellent studies find almost negligible (Kuhn et al. 2009; Black et al. 2015) and even zero effects (Salm 2009; Browning et al. 2006; Roulet A: The Effect of Unemployment on Health: Evidence from Denmark, unpublished). Most of the previous studies in this literature employ plant closure to identify the effects of job losses on health. This approach provides a plausible exogenous source of variation to entries into unemployment. However, there may be some concerns when it comes to estimating longer term effects of unemployment itself because of the non-random nature of exits from unemployment.

In this paper, we exploit the unique situation in the Spanish labor market following the Great Economic Recession to overcome this potential limitation. Namely, we take advantage of the severe-and lasting-impact of the economic recession on job destruction to estimate the effect of job losses on mental health with only minimal selection out of unemployment. Over the last decade, the deterioration of employment opportunities in Spain was directly linked to workers' exposure to the construction sector. In addition, the high concentration of job destruction in this sector, where workers with little education had been attracted by a decade of expansion, made unemployment a very hard trap to 
escape. Hence, the negative labor demand shock resulting from the collapse of the housing market resulted in job losses followed by a very low re-employment probability for the most affected workers-namely, unskilled young workers in construction (ILO 2014). We show that long-term unemployment in this group increased dramatically and argue that the nature of this economic episode allows us to identify the effect of job losses on health minimizing the potential biases resulting from the selection of workers in and out of unemployment.

Our identification strategy follows that in Bartik (1991) and Blanchard and Katz (1992) where the regional composition of the economy (or the importance of the construction sector) at an initial period (pre-crisis years) is used to predict exogenous changes in employment over time. Our IV estimates suggest an important negative effect of unemployment on mental health, while less robust findings appear on other health outcomes, including death rates. We also find that the IV estimates are larger than those suggested by Fig. 1 or the OLS regressions. These findings support the view that selection out of unemployment might be an important factor when analyzing the relationship between unemployment and mental health. In this view, laid-off workers from construction got trapped in long-term unemployment by drastic shifts in the demand for labor. This affected their mental health through stress and feelings of uselessness and helplessness.

Our results speak directly to the literature on hysteresis in unemployment (see Blanchard (2018), for a recent review). Declining mental health is a plausible reason why unemployment leads to an increased marginalization. Given our findings, understanding hysteresis might then require a mix of macro- and micro-evidence because the effects of unemployment on health could be a function of the severity of the macroeconomic shock. If individuals who suffer the largest health losses select out of unemployment, we may observe relatively minor and not persistent health effects of common economic shocks. However, we expect important and persistent negative health effects-and hence larger hysteresis-after large industry shocks which are hard to escape.

In the following section, we review the related literature. Section 3 presents evidence on the changes in unemployment and unemployment duration with a focus on the construction sector. Section 4 discusses our data sources, and Section 5 provides a first look at the data. Section 6 introduces the empirical model and discusses our identification strategy. Section 7 presents our estimation results and some robustness checks. This is followed by some concluding remarks in Section 8 .

\section{Related literature and contribution}

It is a well-documented fact that unemployment is associated with bad health outcomes (Kasl and Jones 2000). However, an unresolved debate remains about the nature of this association. At least three different mechanisms can lead to the observation that unemployed workers are less healthy than employed ones. First, ill workers are more likely to become unemployed (Böckerman and Ilmakunnas 2009; García-Gomez et al. 2010). Second, there is evidence that poor health causes longer unemployment spells (Stewart 2001). Finally, unemployment itself can lead to a deterioration of health.

The existing literature suggests that unemployment can adversely affect health and wellbeing through two main channels. First, unemployment has immediate monetary costs. The sharp and persistent reduction of income that accompanies job losses (Ruhm 1991, Jacobson et al. 1993, and Eliason and Storrie 2006) typically force unemployed individuals 
to make hard economic adjustments that may negatively affect, among other things, the quality of their nutrition, housing, and health care. In addition, financial strain has consistently been found to be an important predictor of psychological distress among the unemployed (Kessler et al. 1987; Jackson and Warr 1984). Second, unemployment may produce important non-monetary and social consequences related to the loss of work relationships, self-esteem, sense of control, meaning of life, and time structure that may all negatively affect (mental) health (Erikson 1959; Seligman 1975; Jahoda 1982; Warr 1987; Goldsmith et al. 1996). Particularly relevant for our study is the phased response in emotional well-being found by Hill (1977) and others. In the first stage of the unemployment spell, the individual is still optimistic. In the second stage, when efforts to obtain work fail, the individual becomes pessimistic and suffers active distress. In the third stage, the unemployed become fatalistic and adapts to the new state. Helplessness becomes acute among long-term unemployed.

Our paper focuses on the identification of the causal impact of being unemployed on individual health and mental health. This is empirically challenging as the researcher needs to effectively deal with reverse causality, whereby poorer (mental) health may determine selection into both unemployment and longer spells of unemployment. Firm downsizing and plant closures have been often used to identify the causal effect of job loss on health. These events provide an arguably exogenous source of variation for the unemployment entry rate as job losses are unlikely to be related to workers' health. ${ }^{2}$ Using this approach, several studies have documented higher risk of mortality after job displacement for affected workers (Sullivan and von Wachter 2009; Eliason and Storrie 2009a; Browning and Heinesen 2012). Higher utilization of sickness benefits and disability pension has also been documented as a consequence of firm downsizing or closure (Rege et al. 2009). Further, there is evidence that job displacement increases the likelihood of reporting poor health, suicide attempts, hospitalization, mental illness, and substance abuse (Eliason and Storrie 2009b; Browning and Heinesen 2012; Black et al. 2015; Schaller and Stevens 2015).

However, this literature is characterized by a relatively large heterogeneity in the magnitude and statistical significance of the estimated effects. Indeed, studies that identify very large health effects on individuals laid off due to plant closures (Sullivan and von Wachter 2009; Browning and Heinesen 2012) coexist with papers that estimate almost negligible (Kuhn et al. 2009; Black et al. 2015) and even zero effects (Salm 2009; Browning et al. 2006; Roulet A: The Effect of Unemployment on Health: Evidence from Denmark, unpublished). Differences in the overall labor market conditions laid-off workers face after dismissal may explain why these studies reach very different conclusions on the effect of unemployment on health. Eliason and Storrie (2009a), for instance, acknowledge that their plant closure approach may underestimate the true impact of becoming unemployed because the displaced workers in their sample faced a very buoyant labor market and many of them got new jobs without even experiencing unemployment. Similarly, Browning and Heinesen (2012) find that job losses in high unemployment areas have larger effects on mortality than job losses in less economically depressed areas. ${ }^{3}$ (Roulet A: The Effect of Unemployment on Health: Evidence from Denmark, unpublished) further suggests that the generosity of unemployment benefit schemes and welfare state may also affect the magnitude of these effects. An alternative plausible explanation is the non-random process of unemployment exits. For example, there is evidence that individuals who suffer more from being unemployed exert a larger effort in searching for a job 
(Gielgen and van Ours 2014) and are less likely to remain unemployed for longer periods of time (Clark 2003 and Clark et al. 2001).

Our contribution to this body of evidence is twofold. First, we study the case of Spain using the commonly employed shift-share instrument (Bartik 1991), which combines the local industry composition with national changes in employment across industries to isolate the local labor demand shocks. ${ }^{4}$ The special features of the Spanish economic crisis allow us to identify the effect of the collapse of a large part of an industry, namely the construction sector, on those workers exposed to it. ${ }^{5}$ This sets us apart from the literature studying unemployment in normal times and from the literature on plant closure, which has not analyzed situations in which half of the plants in a region close simultaneously-a situation which was not uncommon during the Spanish crisis. Second, we provide a conceptual explanation for our findings. If those potentially most affected by job losses are not able to find employment quickly, a channel which holds down the effect of unemployment on health in normal times, the estimated effect will be magnified. The role of endogenous job search has been previously considered in the literature, but the size of our estimates suggests it is not a negligible factor during a large crisis. This has significance beyond the case of Spain which we turn towards in the conclusion.

Our paper is also related to another stream of the literature that has examined the relationship between health and aggregate economic conditions, in particular unemployment. Several authors have documented that aggregate mortality is strongly procyclical (Ruhm 2000, 2005; Miller et al. 2009; Stevens et al. 2015), but that mental health (measured by the suicide rate) deteriorates during economic downturns (Ruhm 2003). The literature on happiness and subjective well-being has also shown that higher levels of unemployment are linked to lower reported happiness (Clark and Oswald 1994; Winkelmann and Winkelmann 1998; Di Tella et al. 2001; Stutzer and Lalive 2004). Studies based on individual data also identify a positive effect of unemployment on suicide, depression, physician consultations, illness episodes, and substance abuse (see, among others, Dooley et al. 1996 and Browning and Heinesen 2012). In a recent paper also using individual data, (Colantone I, Crinò R, Ogliari L: Globalization and Mental Distress, unpublished) document a negative relationship between labor market conditions (measured by import competition) and mental distress.

Finally, our results directly speak to the literature which tries to explain hysteresis in the economy and, in particular, in the labor market. One hypothesis in this regard is that the longer workers are unemployed the less they become tied to the job market. ${ }^{6}$ This means that large negative shocks to the economy have a lasting impact on the labor market. Our results are very much in line with supply-side explanations for this phenomenon such as in Krueger and Mueller (2011). In particular, if in normal times those who anticipate damage to their mental health select out of long-term unemployment, then we should expect to see worse treatment effects and marginalization in groups that are pushed into unemployment by a large exogenous shock which is hard to escape. ${ }^{7}$

\section{The Spanish economic crisis}

In this section, we describe the main aspects of the economic crisis in Spain. In particular, we highlight three important features that are relevant for our empirical strategy. First, the labor market shock experienced by the Spanish population was severe when compared to other countries. Unemployment increased dramatically (by more than 15 
percentage points), affecting mainly young and unskilled workers. Second, the negative shock to employment opportunities was mainly concentrated in the construction sector. Third, individuals who lost their jobs faced extremely adverse labor market conditions leading to a dramatic increase in the average duration of unemployment spells.

Figure 2 plots the unemployment rate (panel a) and the share of long-term unemployed workers (i.e. people who have been unemployed for 12 months or more; panel b) in four OECD countries (USA, UK, Germany, and Spain) over the period 2000-2016. From Fig. 2a we can see that the unemployment rate grew from a level similar to Germany in 2007 to a rate between 15 and 20 percentage points higher a few years later. Most recently, unemployment has slightly declined but it still remains remarkably high. Figure $2 \mathrm{~b}$ shows that, with a delay of 2 years, the share of long-term unemployment also increased dramatically in Spain. Whereas $20 \%$ of all unemployed workers were long-term ones in 2008, this share increased to close to $50 \%$ in 2012 . This means that a large share of individuals who lost their job in 2008 and 2009 could not find a new one afterwards. Moreover, a striking feature of both panels in Fig. 2 is the persistency in the level and the duration of unemployment.

Figure 3 highlights the connection between the size of the construction sector and the increase in unemployment in Spain. The $y$-axis displays the change in the unemployment rate between 2006 and 2011 in the 52 Spanish provinces. On the $x$-axis, we report the share of employment in the construction sector over the total active population in 2006, before the crisis hit in 2007. The figure clearly shows that the largest increases in unemployment were observed in those regions where employment in construction was the highest before the crisis. Some provinces had almost 1/5 of their active population employed in construction when the housing market collapsed. Five years later unemployment had risen by a similar amount. In contrast, in regions with less construction, the unemployment rate displayed a much less pronounced increase.

Individual reports on unemployment in the Spanish National Health Survey (NHS) sample (the survey we use for our empirical analysis; see Section 4) also reveal these dramatic changes in the labor market. Figure 4a shows how the distribution of unemployment duration in the NHS sample changed dramatically between years 2006 (blue bars) and 2011 (red plus blue bar). In 2006, about half the unemployed workers experienced spells that lasted less than 6 months. As a result of the economic downturn, this group increased slightly from over $5 \%$ of the active population in 2006 to about $7 \%$ in 2011 . Most

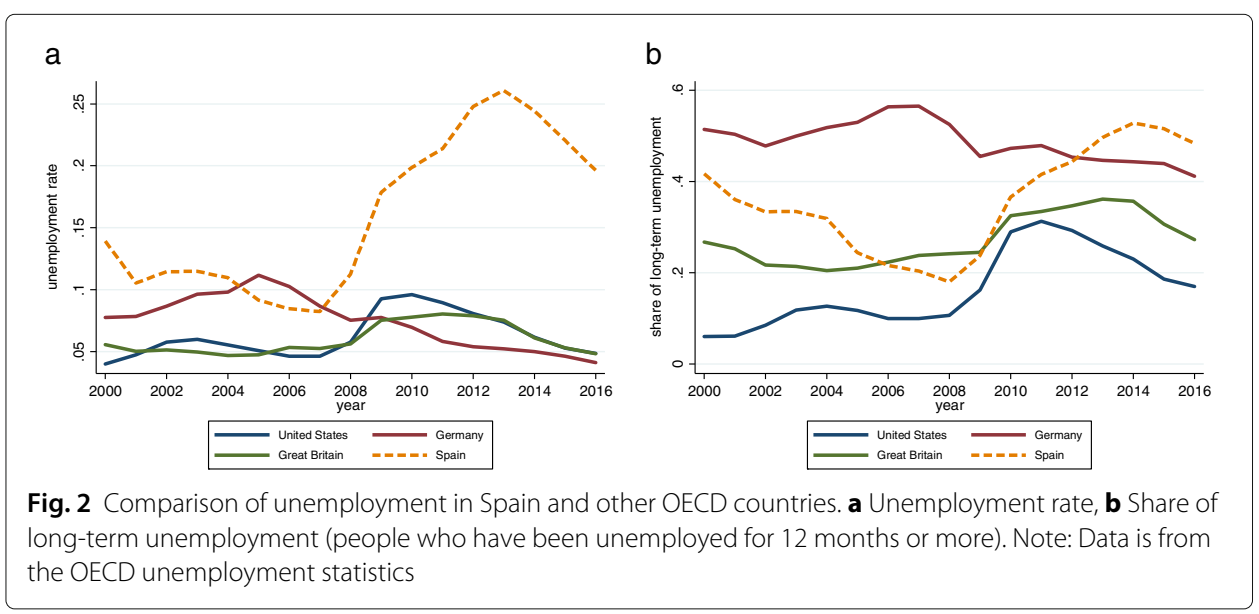




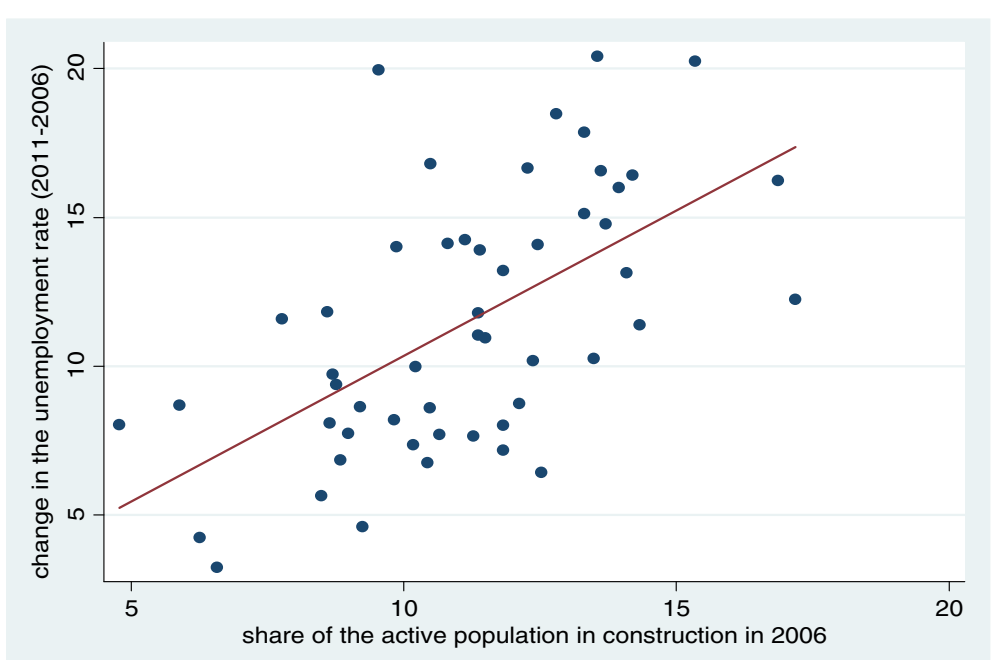

Fig. 3 Changes in unemployment and the construction sector. Note: Each point represents one of the 52 Spanish provinces. Source: Spanish Labor Force Survey
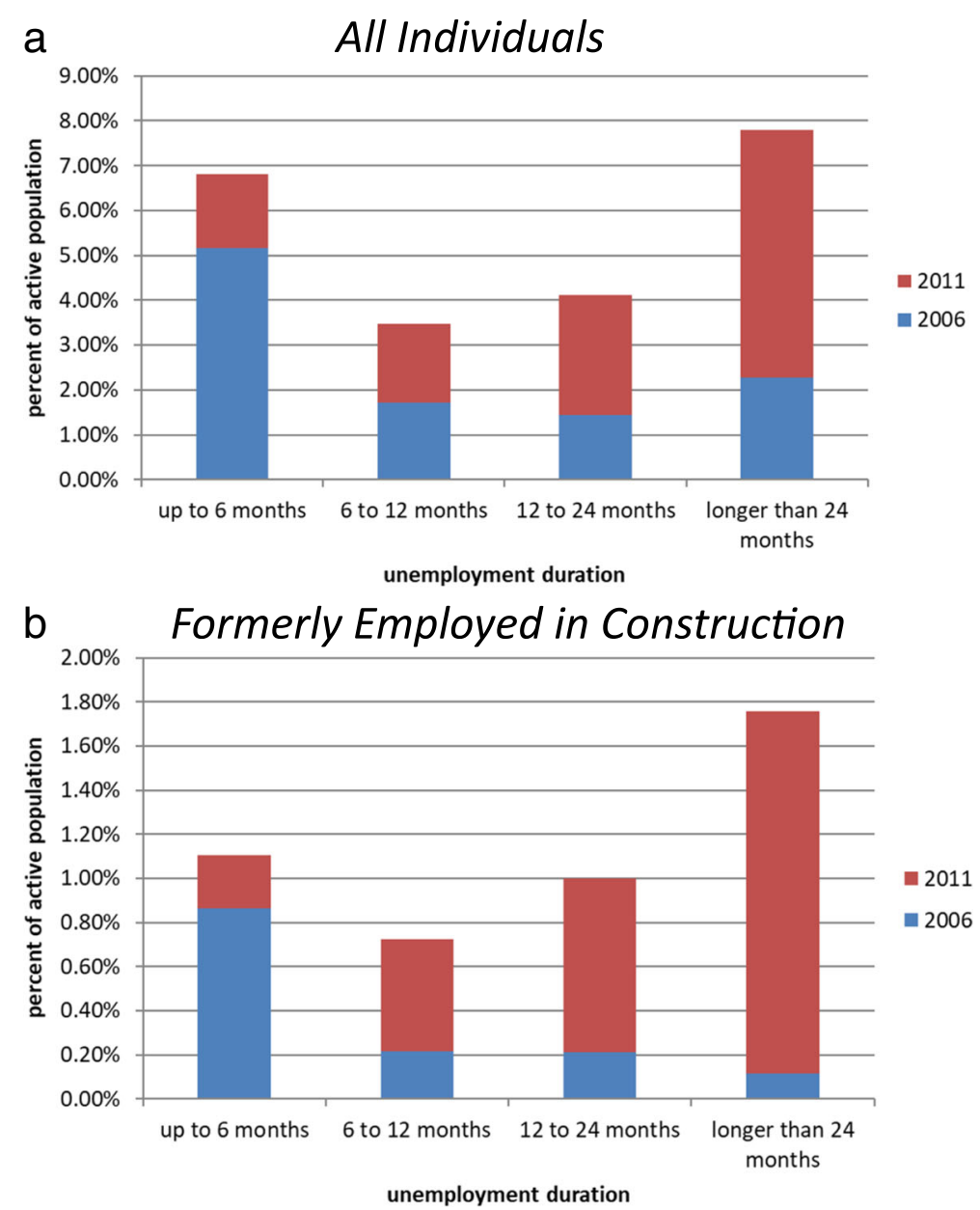

Fig. 4 a Increase in unemployment duration (all individuals). b Increase unemployment duration (formerly employed in construction). Note: Authors' elaboration from Spanish National Health Survey data 
of the additional unemployed workers, however, experienced longer spells. In particular, the group with unemployment spells of more than 2 years more than tripled in size from about $2 \%$ in 2006 to almost $8 \%$ in 2011 . Construction workers were most affected by long-term unemployment. In the National Health Survey, individuals are asked in both 2006 and 2011 whether their current or last employment was in construction. Figure 4b shows unemployment duration in this group, again as percent of the active population. Unemployment in this group increased particularly strongly and an overwhelming majority of the additional unemployed was without employment for longer than a year in 2011 . It should be clear from these numbers that, if anything, the pattern of unemployment duration displayed in Fig. 2 should be even more extreme for construction workers.

This descriptive evidence indicate that workers in construction were severely affected by the economic recession. They not only faced massive layoffs that largely contributed to a sharp increase in the aggregate unemployment rate but also had a hard time finding new jobs opportunities in alternatives industries of a depressed labor market. As a result, a large percentage of construction workers had very low re-employment chances and became long-term unemployed.

\section{Data and descriptives statistics}

Our empirical analysis is based on data from the Spanish National Health Survey (Encuesta Nacional de Salud). This survey contains individual information on physical and mental health, employment status as well as other socioeconomic characteristics. The NHS is a cross-sectional survey that exists for various years between 1987 and 2011. Unfortunately, the questions are often not fully comparable across different waves of the survey. Most of our analysis will thus focus on the comparison between the year 2006 (just before the collapse of the Spanish economy) and 2011 (in the middle of the economic downturn), using the last two waves of the survey that asked almost identical questions. We present additional results for a general health measure that was consistently recorded in the years 2001, 2003, 2006, and 2011. ${ }^{8}$

Table 1 presents descriptive statistics for the variables we use from the NHS. We restrict the analysis to individuals older than 16 and younger than 65 . Unless stated otherwise, we only look at the active population. The sample size is about 46,000 in the larger sample and almost 25,000 in the last two waves (2006 and 2011), although it varies slightly depending on the specific health question we consider. The survey provides very detailed questions on several aspects of health. First, respondents are required to provide a self assessment of their general health status over the last year, classifying it in very good/good/bad/very bad health. We recode this variable giving values of 1 to reports of very good or good health and 0 otherwise. Almost $80 \%$ of our sample reports good or very good health: this share does not change depending on the sample, suggesting a relative stability of subjective health over time. Second, respondents are asked whether they received a diagnosis from a doctor for a set of different illnesses during the last 12 months: chronic back pain, chronic headache, heart attack, stroke, and mental disorder. Of particular interest for us is the question regarding whether the respondent has been diagnosed with a mental disorder (i.e., depression or chronic anxiety): $8.4 \%$ report a mental disorder diagnosis in the surveys 2006-2011. Third, a measure of self-reported mental health is obtained by asking respondents whether they suffer from some mental disorder during the last year. The share of respondents who report suffering from mental disorder 
Table 1 Summary statistics

\begin{tabular}{|c|c|c|}
\hline Variable & Mean & Std. dev \\
\hline \multicolumn{3}{|l|}{ Panel A - NHS $(2001,2003,2006,2011)$} \\
\hline Age & 39.262 & 11.137 \\
\hline Male & 0.583 & 0.493 \\
\hline Secondary education & 0.559 & 0.496 \\
\hline College education & 0.220 & 0.414 \\
\hline Unemployed & 0.162 & 0.369 \\
\hline Reported good health & 0.789 & 0.408 \\
\hline Mental disorder diagnosed by doctor & 0.068 & 0.251 \\
\hline Observations & 46247 & \\
\hline \multicolumn{3}{|l|}{ Panel B - NHS health questions $(2006,2011)$} \\
\hline \multicolumn{3}{|l|}{ Health and Mental Health } \\
\hline Reported good health & 0.790 & 0.407 \\
\hline Mental disorder diagnosed by doctor & 0.084 & 0.278 \\
\hline Mental disorder reported & 0.087 & 0.283 \\
\hline Chronic backpain diagnosed & 0.224 & 0.417 \\
\hline Chronic headache diagnosed & 0.093 & 0.290 \\
\hline Heart attack diagnosed & 0.029 & 0.167 \\
\hline Stroke diagnosed & 0.004 & 0.063 \\
\hline Present or previous employment in construction & 0.109 & 0.311 \\
\hline \multicolumn{3}{|l|}{ GHQ Mental Health Survery (Caseness Coding) } \\
\hline Mental disorder GHQ questionaire total score & 1.292 & 2.299 \\
\hline Lost sleep & 0.240 & 0.427 \\
\hline Felt under strain & 0.257 & 0.437 \\
\hline Unable to enjoy activities & 0.102 & 0.303 \\
\hline Unhappy or depressed & 0.141 & 0.348 \\
\hline Feeling unhappy & 0.059 & 0.236 \\
\hline Unable to concentrate & 0.114 & 0.318 \\
\hline Unable to make decisions & 0.042 & 0.201 \\
\hline Unable to overcome difficulties & 0.120 & 0.325 \\
\hline Unable to face problems & 0.056 & 0.229 \\
\hline Feeling useless & 0.064 & 0.245 \\
\hline Lost self confidence & 0.065 & 0.246 \\
\hline Worthless person & 0.032 & 0.177 \\
\hline Observations & 24856 & \\
\hline
\end{tabular}

(8.7\%) is slightly larger than those reporting to have received a diagnosis for mental disorder.

Health was improving slightly between 2006 and 2011. The percentage of individuals reporting good health increased from 76 to $81 \%$, for example. Reported mental disorders fell from $9 \%$ in 2006 to $7 \%$ in $2011 .{ }^{9}$ However, this positive trend was not uniform: individuals associated with the construction sector reported slightly worse mental health on average in 2011 than in 2006 (see Additional file 1: Table A1).

In 2006 and 2011, the National Health Survey conducted a special module of 12 questions related to mental well-being (see panel B in Table 1) which are part of the General Health Questionnaire (GHQ), a screening instrument developed to identify psychiatric illness (Goldberg 1972). GHQ indexes have been recently used in economic papers to study both mental health (Dustmann and Fasani 2016) and general individual well-being 
(Clark and Oswald 1994 and Clark 2003). ${ }^{10}$ For each question, respondents can choose among four answers: much worse than usual, worse than usual, as usual, and better than usual. Responses to the GHQ questions are coded between 0 and 3, where 3 is always the worst outcome, 1 is the default, and 0 indicates a better than usual status. The GHQ questions can be grouped in three categories. The first group includes stress-related indicators and questions for general well-being (e.g. "In the last couple of weeks have you: ...lost much sleep over worry? ...felt constantly under strain? ...been feeling reasonably happy, all things considered?"). The second category tests the decision-making capacity of individuals (e.g., "In the last couple of weeks have you: ...been able to concentrate on whatever you are doing? ...felt capable of making decisions about things?"). Finally, the third category contains questions about individual self-perception (e.g. "In the last couple of weeks have you: ...felt you were playing useful part in things? ...being thinking of yourself as a worthless person?"). There is substantial variation in responses to the different GHQ items. For instance, about one fourth of the respondents answer "worse than usual" to the questions related to losing sleep over worry or to feeling constantly under strain, while only $3 \%$ report a higher propensity to think of themselves as worthless individuals.

A common procedure in empirical analyses is to aggregate the different GHQ items in a single index. The literature has suggested alternative procedures. We employ the Caseness scale, which counts the number of questions for which the response is in one of the two "worse than usual" categories. That is, it follows the coding 0-0-1-1 and the resulting score runs from 12 (all 12 responses indicating poor mental health) to zero (no response indicating poor mental health). The mean of the Caseness GHQ score in our sample is 1.29 and its standard deviation is 2.29. We also employ the Likert scale, where the responses to each item are scored using the full code (0-1-2-3) and then summed up. Hence, the Likert score varies between zero (no mental distress) and 36 (highest mental distress). In our sample, this measure has a mean of 9.88 with a standard deviation of 4.37. ${ }^{11}$

The GHQ has been criticized as likely to miss long-standing mental health problems. Individuals suffering from chronic conditions may respond "no more than usual" to the GHQ questions and be counted as mentally healthy, as neither the Caseness nor the Likert scale would capture the presence of a disorder in this case. To overcome this problem, we employ the adjusted Caseness scale (Goodchild and Duncan Jones 1985) which differentially treats positive (e.g. “...have you felt capable of making decisions about things?”) and negative (e.g. "...have you lost much sleep over worry?") questions in the GHQ questionnaire. In particular, the $0-0-1-1$ code is used only for positive questions while the coding 0-1-1-1 is used for negative ones. This implies that the answer "as usual" is treated as an indicator of good mental health in the former case and of poor mental health in the latter. The adjusted Caseness scale has mean 3.25 (sd 2.68) in our sample (see Additional file 1: Table A2).

Our analysis with the National Health Survey is complemented with data from several other sources. First, we use data from the Spanish Labor Force Survey (Encuesta de Población Activa - EPA) to capture the exposure of Spanish workers to the economic shock. The EPA sample we use includes 65,000 interviewed households per quarter, which implies approximately 180,000 people. Second, as an additional check of our methodology, we use data from different opinion surveys conducted by the Centro de Investigaciones Sociológicas (CIS) in 2000, 2003, 2008, and 2012. In these years, individuals are asked about their life satisfaction ("In general, how satisfied are you with your 
life?"). The sample for the 4 years contains 7742 individuals, aged 18 to 64 years old. ${ }^{12}$ Third, we use data on deaths from suicides at the province level over the period 2000 to 2012 available from the death records of the Spanish Statistical Office. Finally, we use population data to build rates (i.e., death rate, unemployment rate). These data are gathered from the municipal registry (Padron Municipal) from 2000 to 2011 and can be disaggregated at the provincial level.

\section{Health and unemployment: descriptive evidence}

We start our empirical analysis by estimating the following OLS regression:

$$
\text { health }_{\text {ipt }}=\alpha u_{i p t}+\beta \mathbf{X}_{i p t}+\theta_{p}+\eta_{t}+v_{i p t}
$$

where the dependent variable, healt $h_{i p t}$, is a measure of health for individual $i$, residing in province $p$ at time $t$. The model includes a dummy variable to capture whether the respondent is unemployed, $u_{i p t}$ (our main regressor of interest), a vector of individual socioeconomic characteristics, $\mathbf{X}_{i p t}$, province fixed effects, $\theta_{p}$, year dummies, $\eta_{t}$, and an error term $v_{\text {ipt }}$.

Table 2 shows the first set of results. In the first column, the dependent variable is an indicator that takes value 1 if the respondent declares to be in good or very good health and 0 otherwise. This question is common to all the waves of the survey, and thus, we include in estimation all the observations since $2001 .{ }^{13}$ A gender dummy and an indicator for being younger than 40 are included as additional controls. The estimated coefficient on the unemployment dummy implies that the unemployed are 8 percentage points less likely to report good health (column 1). There is also strong evidence that men and young individuals report better health. In unreported regressions, we find that these results still hold when controlling for education categories or finer age groups.

The remaining columns of Table 2 display the results of an alternative empirical specification employed in most of the paper. This new specification is based on a cell-level panel where cells are defined by three variables: age, sex, and province of residence. We introduce these cells in order to be able to construct a panel that spans different waves of the NHS. Cells, $c$, are defined by:

$$
c:\{\text { under40, province, male }\}
$$

which gives us $2 \times 51 \times 2=204$ cells. The construction of cells $c$ allows us to compare changes in health outcomes within cells over time, holding a combination of individual characteristics (i.e., age and gender) and geography fixed. Accordingly, we include cell fixed effects $\theta_{c}$ in the specification in Eq. (1) and estimate the following model:

$$
\text { health }_{i c t}=\alpha u_{i c t}+\theta_{c}+\eta_{t}+v_{i c t} .
$$

where the dependent variable, health ${ }_{i c t}$, is a measure of health for individual $i$, in cell $c$ at time $t$, and the other variables are as in Eq. (1). We think of these cells as a reasonable measure of the labor market an individual belongs to. ${ }^{14}$ The new specification is quite demanding as it now exclusively exploits within-cell variation, allowing average health levels to vary across cells. Note that when we use cell fixed effects, we control for any unobservable difference that may exists between these different labor markets.

Estimates reported in column (2) of Table 2 show that our more stringent specification provides very similar results regarding general health. Columns (4) to (8) maintain the 


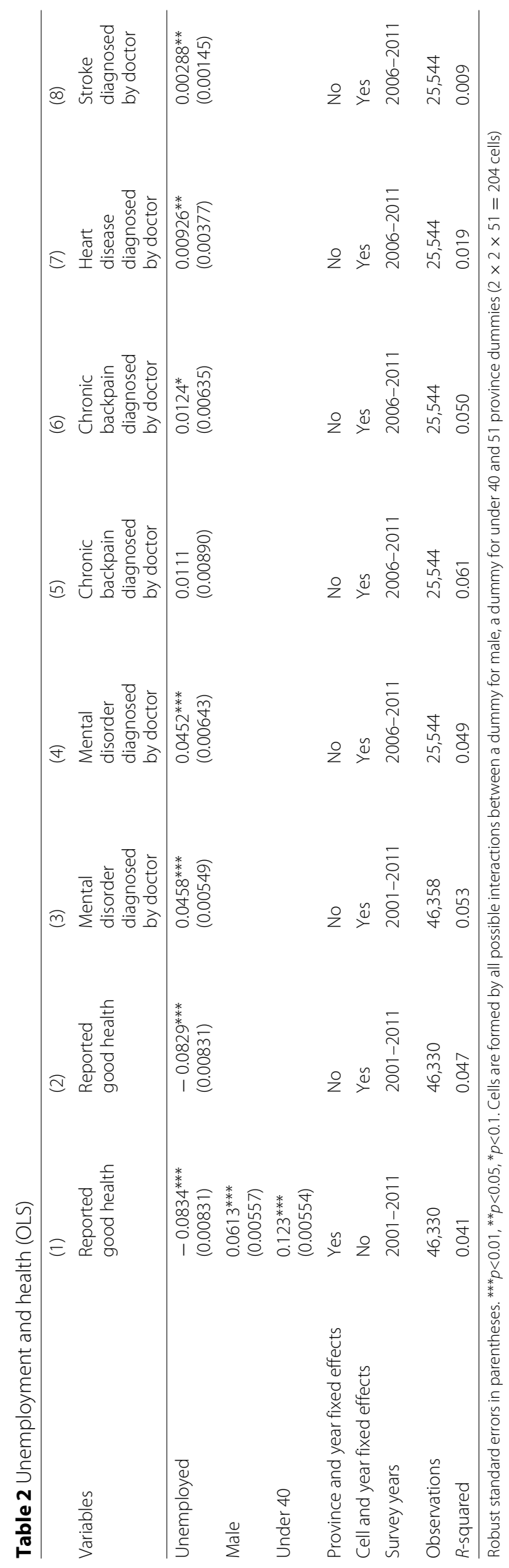


cell specification and columns (4) to (8) restrict the sample to the comparable survey waves in 2006 and 2011 to look at additional outcomes. Column (3) shows that mental disorders are 5 percentage points more likely among the unemployed. Other illnesses like chronic headaches and heart attacks are also more likely among the unemployed. However, here, the magnitudes are much smaller. Heart attacks, for example, increase by only one percentage point with unemployment. ${ }^{15}$

The estimates in Table 2 highlight a clear correlation between mental health and, to a lesser extent, health in general and unemployment; however, they are uninformative about which direction causality runs. To this end, we employ an instrumental variable strategy based on the massive destruction of jobs in the construction resulting from the bursting of the Spanish housing bubble.

\section{Empirical strategy}

\subsection{Theoretical discussion}

Our empirical analysis exploits the features of the recent Spanish economic crisis to identify the causal effect of unemployment on health. We employ a two-stage least square estimation technique where the individual unemployment variable in Eq. (2) is instrumented using cell-level exposure to the collapse of employment opportunities in the construction sector. We argue that this instrument, in the context of the Spanish recession, satisfies the exclusion restriction, by generating job losses that are exogenous to unobserved individual characteristics. We further discuss that, in our context, re-entry into employment is almost impossible, a fact that bears important implications for the interpretation of our results. We next examine these two assumptions theoretically in a static framework. ${ }^{16}$

Let us first assume that the effect of unemployment on health is homogeneous in the population. We could estimate the following equation:

$$
h_{i t}=\alpha u_{i t}+\mu_{i}+\epsilon_{i t}
$$

where $h_{i t}$ is (mental) health status of individual $i$ at time $t, u_{i t}$ is a dummy equal one if the individual $i$ is unemployed at time $t, \mu_{i}$ is an individual fixed effect, and $\epsilon_{i t}$ is an error term. ${ }^{17}$ If being unemployed negatively affects an individual's health, we should expect the coefficient $\alpha$ on the unemployment dummy to be negative. As discussed in Section 2, however, there are many reasons to expect the individual unemployment status to be correlated with the individual fixed effect. Estimating Eq. (3) with OLS would then produce biased estimates of the coefficient of interest:

$$
\alpha_{O L S}=\alpha+E\left(\mu_{i} \mid u_{i t}=1\right)-E\left(\mu_{i} \mid u_{i t}=0\right) .
$$

In particular, under the realistic assumption that healthier individuals are less likely to be unemployed-for instance, because productivity is increasing in health and employers prefer hiring healthier individuals - we would expect individual fixed effects and the probability of being unemployed to be negatively correlated. This implies that the bias is negative $\left(E\left(\mu_{i} \mid u_{i t}=1\right)-E\left(\mu_{i} \mid u_{i t}=0\right)<0\right)$ and that the OLS estimator would be downward biased, exaggerating the negative effect of unemployment on health. In this context, the OLS estimate of the $\alpha$ coefficient would be larger in absolute value than an IV estimate that managed to remove the negative selection bias. 
However, there is no reason to expect the effect of job loss to be homogenous in the population. We can expect different individuals to react differently to the experience of being unemployed. Being laid off can be a psychologically devastating experience for some people whereas for others it may just represent an unfortunate incident in life. ${ }^{18}$ With heterogeneous effects of unemployment on health, the coefficient $\alpha_{i}$ varies at the individual level and Eq. (3) can be re-written as:

$$
h_{i t}=\alpha_{i} u_{i t}+\mu_{i}+\epsilon_{i t}
$$

We define the average treatment effect (ATE) of unemployment in the population as $\alpha^{A T E}=E\left(\alpha_{i}\right)$ and re-write equation (4) as:

$$
h_{i t}=\alpha^{A T E} u_{i t}+\left(\alpha_{i}-\alpha^{A T E}\right) u_{i t}+\mu_{i}+\epsilon_{i t}=\alpha^{A T E} u_{i t}+e_{i t}
$$

where $e_{i t}=\left(\alpha_{i}-\alpha^{A T E}\right) u_{i t}+\mu_{i}+\epsilon_{i t}$. In this case, the OLS estimate of the coefficient $\alpha$ is:

$$
\alpha_{O L S}=\alpha^{A T E}+E\left[\mu_{i} \mid u_{i}=1\right]-E\left[\mu_{i} \mid u_{i}=0\right]+E\left[\left(\alpha_{i}-\alpha^{A T E}\right) \mid u_{i}=1\right] .
$$

In the presence of heterogeneous effects of unemployment on health, the selection bias has now two components. First, the term $\left[E\left[\mu_{i} \mid u_{i}=1\right]-E\left[\mu_{i} \mid u_{i}=0\right]\right]$ which captures the selection on underlying health status into unemployment. This term also appears in the case of homogeneous effects and is expected to be negative if healthier individuals are less likely to be unemployed. The second term, $E\left[\left(\alpha_{i}-\alpha^{A T E}\right) \mid u_{i}=1\right]$, is the selection on the "returns" to unemployment, and it reflects the heterogeneity across individuals in the effect of unemployment on health. Its sign depends on how these effects are associated to the individual probability of being unemployed. If individuals who suffer the most from unemployment (i.e., individuals whose $\alpha_{i}$ is even more negative than the average in the population, $\alpha^{A T E}$ ) have stronger incentives to exert effort to retain their jobs (if employed) and to search more intensively to find a new job (if unemployed), we should expect this term to be positive. ${ }^{19}$ Indeed, if individuals with higher potential (mental) health loss from unemployment have a lower probability of being unemployed, unemployed workers should have $\alpha_{i}$ above the average in the population. ${ }^{20}$ Therefore, in the presence of heterogeneous effects of unemployment, we have two sources of bias in the OLS estimator and we may expect them to have opposite signs. ${ }^{21}$ Differently from the homogenous case, it is now unclear whether the OLS estimator would over-rather than under-estimate the causal parameter of interest. The bias will depend on whether selection in and out of unemployment correlates with health status, with the health loss in unemployment or with both.

In order to retrieve the causal effect of unemployment on health, one needs an instrument that is uncorrelated with both the unobservable health status of workers $\left(\mu_{i}\right)$ and the unobservable individual "health effect" from being unemployed $\left(\alpha_{i}\right)$. In other words, one would need an exogenous shock that pushes individuals into unemployment irrespective of their unobservables characteristics. The literature has proposed to use plant closures as instrument in this context (Sullivan and von Wachter 2009; Eliason and Storrie 2009a; Browning and Heinesen 2012; Black et al. 2015). When a plant shuts down, all employees are generally laid off and, for these workers, the entry into unemployment is orthogonal to their unobservable individual characteristics.

The instrument we propose in this paper is based on the collapse of an entire sectorthe construction sector in Spain-and follows a similar logic. Workers employed in this 
sector suddenly lost their jobs, irrespectively of their underlying health status and of the effect that being unemployed may have produced on their health. In the presence of heterogeneous effects of unemployment on health, our IV strategy identifies a Local Average Treatment Effect (LATE) on a specific population of compliers, namely workers who entered unemployment as a consequence of the collapse of the construction sector but who would have been employed in the absence of this aggregate macro shock. If these workers felt particularly distressed by entering unemployment-because it was an unexpected event, they lost relatively well-paid occupations, they had low expectations of finding an alternative job, etc. (see Section 3)-the LATE effect we estimate may well be larger than the average treatment effect in the population.

Both the plant and the sector closure approach arguably generate an initial quasirandom assignment to unemployment. From the day after being laid off, however, fired workers will start reacting differently to their new status. In particular, we should expect those who fear to suffer the most from being jobless to more actively search for employment (Gielgen and Van Ours 2014). Over time, this endogenous selection out of unemployment will imply that those who remain unemployed suffer less from being jobless. We can interpret this selection as (endogenous) imperfect compliance with respect to the initial random assignment. In this regard, the plant and the sector closure differ along one important dimension. Workers laid off due to a negative idiosyncratic shock that hit their plant will look for a job in a labor market that is generally not experiencing adverse conditions. They may relatively quickly move out from unemployment, find a job in a new firm that values their skills, and minimize the damage that remaining unemployed may cause on their physical and mental health (Black et al. 2015). In contrast, workers who become unemployed because of the collapse of their entire sector of employment may have a very hard time in finding an alternative occupation. They will likely be trapped in unemployment until they manage to update their skills and change sector. ${ }^{22}$ These differential unemployment exit rates also imply that becoming jobless due to the collapse of a sector is a much more severe treatment than losing the job due to a plant closure. Not only the treatment is more persistent but also agents who anticipate this longer persistency may suffer even more from losing their job. If being fired is always a disappointing experience, entering unemployment with the expectation of remaining in that status for a long period is likely to magnify its distressing effects. Using our identification strategy, therefore, we would expect to observe larger effects on health relative to papers that instead based their identification on firm closures.

\subsection{Construction of the instrument}

The previous discussion highlights that we need a variable that captures exogenous job losses and homogenous re-employment probabilities across workers. The evolution of employment in the Spanish construction sector can serve as an instrument for both. First, the collapse of the sector meant that individual fortunes were driven by an exogenous shock. Between 2007 and 2012, employment fell by more than $60 \%{ }^{23}$ Many businesses had to close: bankruptcies in construction shot up from just around 200 per year in the period 2005 to 2007 to around 1500 per year in the period 2008 to 2010, and they reached 1900 in 2011 (Source: Spanish Statistical Office). The increase in bankruptcies was not only in absolute terms but also in relative terms: about 33\% of all bankruptcies in Spain between 2008 and 2010 were by companies in construction. This suggests that if we use 
employment in construction as an instrument for unemployment, we will be capturing job losses due mostly to plant closures from the year 2007 onwards. Second, workers in construction were often unskilled with a training very specific to the sector. Thus, as a result of the collapse, they had a hard time in finding a new job and were trapped in unemployment for a long period. ${ }^{24}$

We build our instrument relying on the heterogenous exposure of different groups to the construction sector. The idea behind our identification strategy is to use changes in the demand for labor at the aggregate level as an instrument for unemployment at the cell level. Our instrument builds on the strategy in Bartik (1991) and Blanchard and Katz (1992) whereby the industrial composition of the economy at an initial period is used to predict exogenous changes in employment over time.

To implement our instrument, we use the Spanish Labor Force Survey (EPA) data and aggregate to the cell level to generate a measure of the employment shock in the different sectors of the Spanish economy. ${ }^{25}$ As before, we use cells spanned by three characteristics-age, sex and province of residence: $c=\{$ under40, province, male $\}$. For each of these cells, we construct employment shares by 10 industries $(j)$ in $2000 .{ }^{26} \mathrm{We}$ refer to these shares as $s_{c, j, 2000}$. As a second step, we calculate the change in aggregate employment in industry $j$ in year $t$ at the national level as:

$$
g_{j t}=\left(E_{j, t}-E_{j, t-1}\right) / E_{j, t-1} .
$$

where $E_{j, t}$ is the number of workers in industry $j$ and year $t$. We focus on employment changes as it gives us a measure of the intensity of employment shocks in each period. Both our first and second stage results are robust to using employment levels or the change in levels.

Figure 5 shows employment growth in Spain. We plot the average employment growth for all sectors with a dashed line and employment growth in construction with a solid one. The picture shows that until 2007, employment was growing in Spain, but the boom was particularly large in construction where growth was above average in all years. However, in 2007, the shock hit and employment fell across the board. The shock was particularly strong in construction where employment shrank by more than $20 \%$ in 2009 and growth was below -10 percent in all years after 2007. As a result, more than $60 \%$ of all jobs that existed in construction in 2007 were lost in the following years. This was a very drastic development even when compared to the generally dramatic change in the Spanish labor market, where most sectors shed about 15 percent of employment after 2007.

We use the interaction between the share of employment in construction at the cell

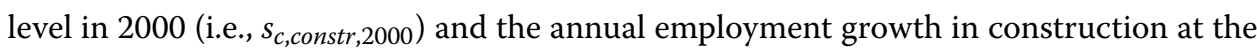
national level (i.e., $g_{\text {constr }, t}$ ) as our main instrument for cell unemployment. That is:

$$
\text { construcIV } V_{c, t}=s_{c, \text { constr }, 2000} * g_{\text {constr }, t} .
$$

As an alternative, we also employ an instrument based on total employment growth:

$$
\text { employmentI } V_{c, t}=\sum_{j} s_{c, j, 2000} * g_{j, t} \text {. }
$$

Our first stage regression then follows:

$$
u_{i c t}=\delta \text { construcIV } V_{c, t}+\theta_{c}+\eta_{t}+\mu_{i c t}
$$




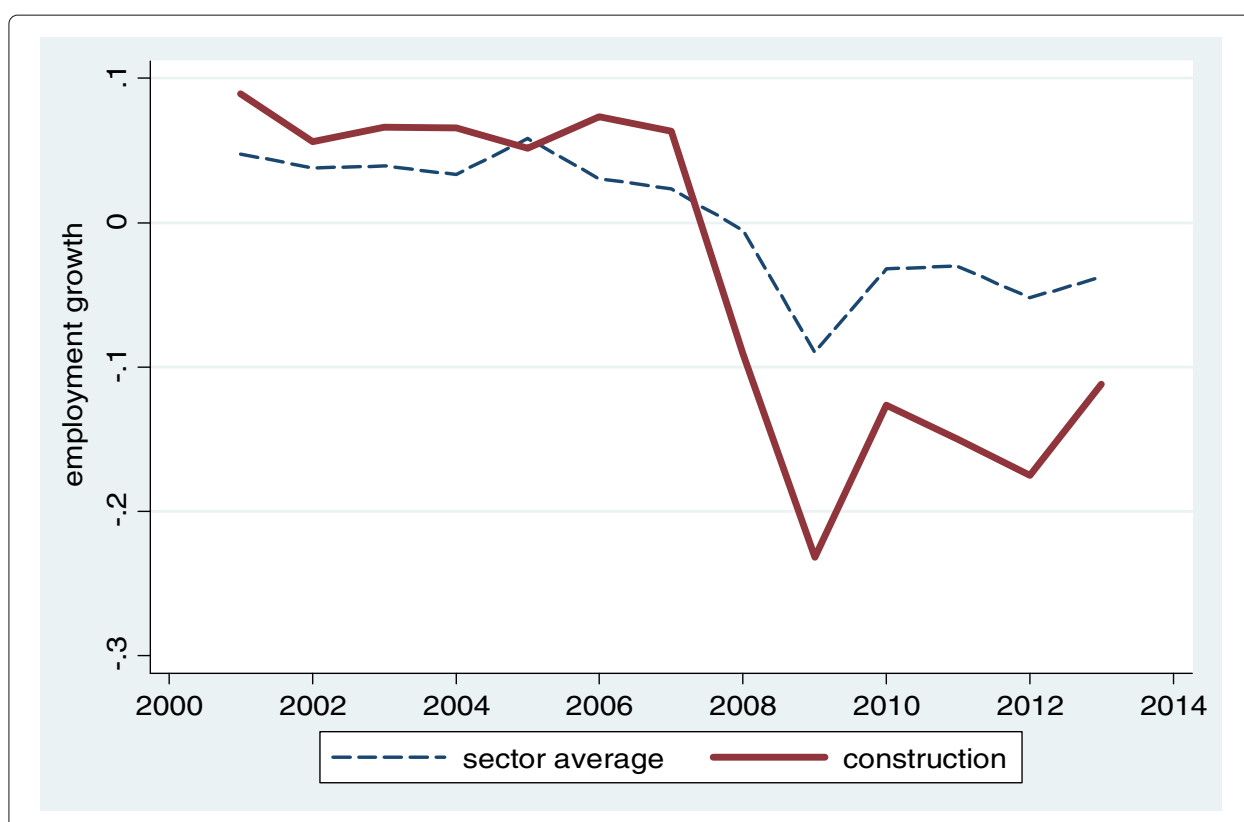

Fig. 5 Employment growth in Spain. Source: Spanish Labor Force Survey

where the unemployment status of individual $i$, in cell $c$, at time $t$, is regressed on the cell-specific instrument. The regression includes a full set of cell fixed effects, $\theta_{c}$, and year fixed effects, $\eta_{t}$. In this specification, the parameter $\delta$ captures the change in unemployment for individuals which can be explained by the change in job opportunities in construction. When estimating this first stage equation, we always cluster standard errors at the cell-level (that is, at the level of variation of our instrument).

The idea behind this instrumental variable approach is that aggregate changes in employment are not driven by cell-specific characteristics. Moreover, its interaction with the industry composition in 2000 ensures that the exposure of cells to construction is predetermined. It is important to note that the effects identified through this approach are driven by changes at the cell level (i.e., by changes within each of the over fifty Spanish provinces). This implies that they cannot be explained by changes in the local economic climate or public sector spending at the provincial level that may directly affect health and mental health of resident workers. As a matter of fact, we show in the robustness section that our findings strengthen when we control for province/year fixed effects (see Section 7.3).

A potential concern regarding our IV approach is the possibility that changes in aggregate unemployment may directly influence workers' health, beyond the effect which goes through individual unemployment. As a matter of fact, the sudden deterioration of labor market conditions may negatively affect all workers, irrespectively of their employment status. Employed workers, for instance, may suffer from perceiving a reduction in job security and from worsening working conditions. The inclusion of province/year fixed effects-as mentioned in the previous paragraph-captures any such effect that takes place at the provincial level. Nevertheless, one may still worry that workers' (mental) health is directly affected by what happens at a finer-grained definition of labor market, such as the cells we created (still, over and above the effect of their individual employment 
status). This would lead to a violation of the exclusion restriction as our instrument (predicted cell unemployment) would be correlated with a variable (cell unemployment) that is hidden in the error term in our specification. Although this is a legitimate concern, in our empirical analysis, we fail to find any evidence that cell-level unemployment produces a statistically significant effect on individual health (see Section 7.3). This evidencetogether with the estimates that condition on province-year fixed effects-provides strong support for the validity of our empirical strategy.

\section{Results}

\subsection{First-stage estimates}

Table 3 reports variations of the first-stage regression in Eq. (5). Columns (1)-(5) display results for all the waves in the National Health Survey 2001, 2003, 2006, and 2011. Column (1) employs all industries in constructing the instrument. There is a clear negative correlation between predicted employment growth and the level of unemployment at the cell level. In column (2), the predicted level of total employment growth is divided into construction and all other sectors. The results show that employment in construction is a much stronger predictor of unemployment. This is consistent with the much more rapid decline in construction employment relative to other industries (see Fig. 5) and with the idea of construction as being at the centre of the crisis on the Spanish labor market. The estimates in column (3) only include employment growth in construction. The coefficient is -2.26 , which implies that when employment in the sector shrank by about 15 percent this would have led to an increase in the unemployment rate of about 34 percentage points in cells that had all their employment in the construction sector in 2000. This finding is robust to various modifications with respect to the definition of cells (columns

Table 3 Construction sector employment as predictor of unemployment

\begin{tabular}{|c|c|c|c|c|c|c|}
\hline & (1) & (2) & (3) & (4) & (5) & (6) \\
\hline Variables & Unemployed & Unemployed & Unemployed & Unemployed & Unemployed & Unemployed \\
\hline \multirow{2}{*}{$\begin{array}{l}\text { Employment } \\
\text { growth }\end{array}$} & $-2.571^{* * *}$ & & & & & \\
\hline & $(0.603)$ & & & & & \\
\hline \multicolumn{7}{|l|}{$\begin{array}{l}\text { Employment } \\
\text { growth }\end{array}$} \\
\hline \multirow[t]{2}{*}{ (construction) } & & $-2.340^{* * *}$ & $-2.258^{* * *}$ & $-2.325^{* * *}$ & $-2.429^{* * *}$ & $-2.454^{* * *}$ \\
\hline & & $(0.582)$ & $(0.451)$ & $(0.395)$ & $(0.420)$ & $(0.456)$ \\
\hline \multicolumn{7}{|l|}{$\begin{array}{l}\text { Employment } \\
\text { growth }\end{array}$} \\
\hline \multirow{2}{*}{$\begin{array}{l}\text { (not } \\
\text { construction) }\end{array}$} & & -0.278 & & & & \\
\hline & & $(0.968)$ & & & & \\
\hline Cell fixed effects & Yes & Yes & Yes & Yes & Yes & Yes \\
\hline Year fixed effects & Yes & Yes & Yes & Yes & Yes & Yes \\
\hline Survey years & $2001-2011$ & $2001-2011$ & $2001-2011$ & $2001-2011$ & $2001-2011$ & 2006-2011 \\
\hline Observations & 46,358 & 46,358 & 46,358 & 46,275 & 46,358 & 25,544 \\
\hline$R$-squared & 0.067 & 0.067 & 0.067 & 0.085 & 0.081 & 0.068 \\
\hline IV: F-statistic & 18.17 & 12.82 & 25.03 & 34.69 & 33.41 & 29.01 \\
\hline
\end{tabular}


(4) and (5)) and also does not change if we focus on just the last two waves in 2006 and 2011 (column (6)). In all cases, our proposed instrument is a strong predictor of individual unemployment, with F-statistics well above the conventional threshold of 10 for weak instruments (see Table 3, last row).

In our main analysis, we employ as a first-stage the results in column (6). The resulting model provides fitted values, $\hat{u}_{i c t}$, of the unemployment rate of up to $58 \%{ }^{27}$ The average change of $\hat{u}_{i c t}$ across the two waves in the NHS is an increase of 12 percentage points and the maximum increase is 24 percentage points. The group with the biggest increase are men below 40 in provinces with large construction sectors. Our identification strategy relies on the difference of these changes within cells over time, i.e., it tries to understand whether the cell which suffered an increase in unemployment of 24 percentage points also suffered a greater health loss than other cells.

\subsection{Main results}

Table 4 reports our main results from the second-stage regressions of several health and mental health outcomes using the 2006 and 2011 NHS waves. The first column presents the IV estimate of the effect of unemployment on reported good health. The point estimate indicates a large and statistical significant negative effect. Namely, a 10 percentage points increase in unemployment driven by the collapse in the construction sector leads to a 3 percentage points decrease in the probability of reporting good or very good health. This is about a $15 \%$ increase in the probability of not reporting good or very good health in our sample. Columns (2) and (3) in Table 4 also indicate a significant increase in the probability of self-reported mental disorders as well as on that diagnosed by a doctor. The point estimates again indicate that a 10 percentage point increase in unemployment increases the probability of suffering from a mental disorder (both self-reported and diagnosed) by 3 percentage points, which represents an increase of about a third of the sample mean prevalence of mental disorders.

Note that the IV estimates of the effect of unemployment on mental health are larger in magnitude than the OLS reported in Table 2. This larger effect corresponds to the subsample of the population on which the effect is identified, namely workers who lost their job as a consequence of the collapse of the construction sector. As discussed in Section 3, employment in construction fell by about 60\% between 2007 and 2013 and the large majority of those who lost their job in construction, $2.7 \%$ of the active population, slipped into unemployment spells that lasted longer than one year. Accordingly, while workers negatively affected by an idiosyncratic shock can quickly find a new job in any other firm, workers laid off by the shut down of an entire sector find themselves trapped into unemployment. Failure to re-enter employment for those who try hardest might have very high costs on mental health. ${ }^{28}$

We then explore the effect of unemployment on mental health by reporting IV estimates for the individual scores in the General Health Questionnaire (GHQ-12) ${ }^{29}$ Column (4) in Table 4 displays the point estimates on the GHQ score where the 12 individual items are aggregated using the Caseness scale. ${ }^{30}$ The point estimate is positive and statistically significant, indicating that unemployment leads to an increase of 2.1 points on the GHQ 12 point scale. Again, an increase of 10 percentage points in unemployment would therefore lead to an increase by 0.2 points. This is particularly meaningful as a score of 1 or 2 is often used as a threshold in diagnosing mental disorders. In the remaining columns in 


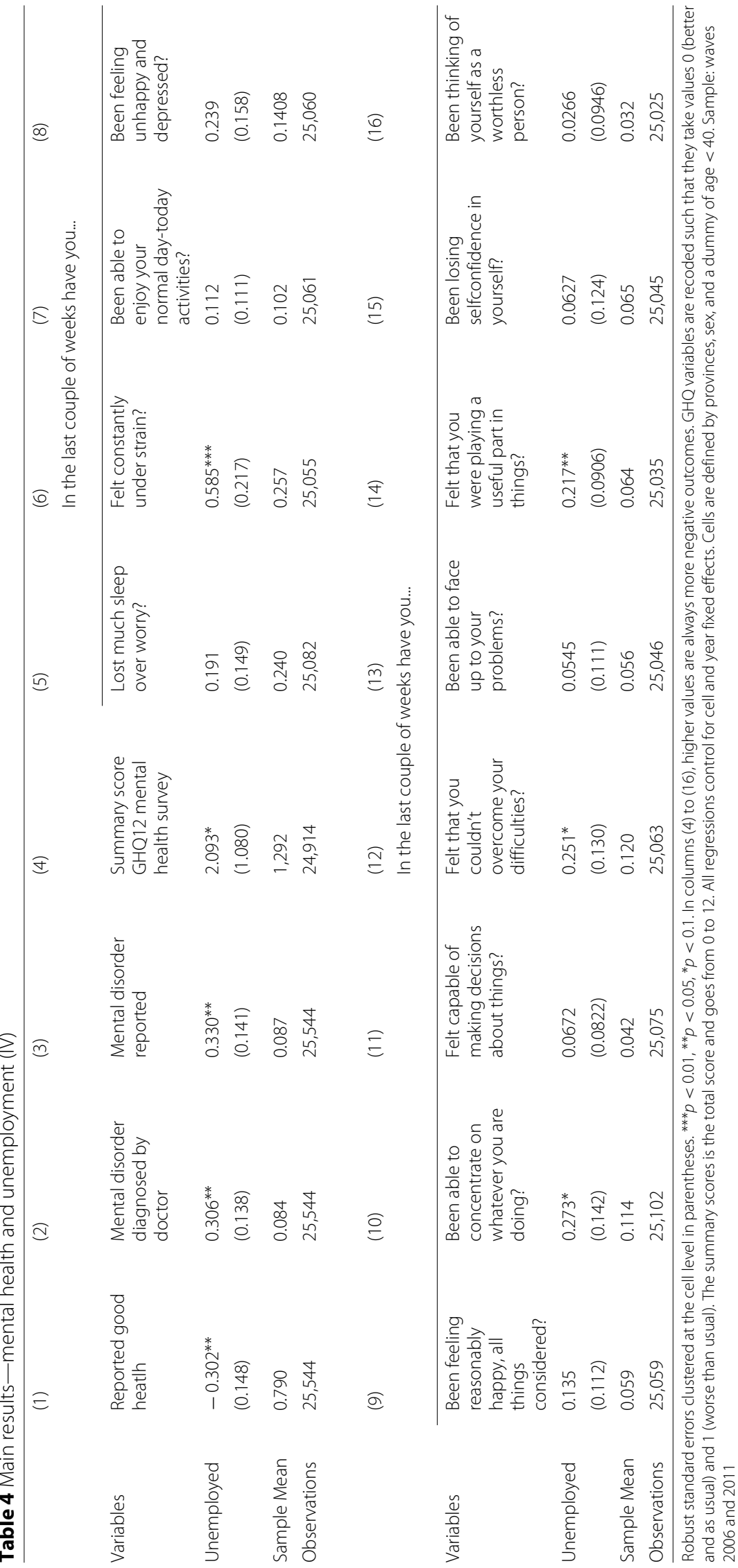


Table 4, we show results on each individual item in the GHQ survey. The response to each item is coded following the Caseness scale, so that a value of 1 means a worse than usual response. On each question, we find a positive and fairly large coefficient. However, only a few are significantly different from zero. In particular, the unemployed are $59 \%$ more likely to report to be more under strain than usual and $27 \%$ less likely to be able to concentrate. Particularly, worrying is the finding that the unemployed are $25 \%$ less likely to report to be able to overcome their difficulties and $22 \%$ less likely to think they play an important part in things. Hence, long-term unemployment in this heavily affected group has led to a feeling of uselessness. These results are particularly worrying as they point towards a danger of the loss in mental health affecting job search.

In order to address some of the concerns in the literature regarding the validity of the GHQ to capture changes in mental health (see Section 4), we employ alternative scales to aggregate the responses to the different 12 items. The results are displayed in the three first columns in Table 5. Column (1) replicates our previous finding using the Caseness scale. Column (2) presents the estimates when using the adjusted Caseness scale that pays attention to the wording of positive and negative questions. It uses the 0-0-1-1 only for positive questions and the coding 0-1-1-1 for negative questions (i.e., "as usual" is interpreted as negative). This alternative coding has been shown to alleviate the potential concerns regarding the ability of the GHQ questionnaire to capture long-term changes in mental health. Finally, column (3) shows the estimates of the Likert scale that exploits the full coding in the survey (i.e., 0-1-2-3). The three alternative coding strategies lead to the same conclusion and indicate that unemployment significantly increases the GHQ score.

The literature has also employed different thresholds in the GHQ score to identify the presence of mental disorders. The remaining columns in Table 5 explore different cutoff points at which a fictitious doctor would diagnose the presence of mental disorders (Goldberg et al. 1998). We explore three different cut-offs: low cut-off, where individuals at the top 30\% of the GHQ score distribution are identified with mental disorders (columns 4-6); medium cut-off, where individuals at the top 20\% of the GHQ score distribution are identified with mental disorders (columns 7-9), and high cut-off, where only individuals at the top $5 \%$ of the score distribution are identified with mental disorders (columns 10-12). Choosing different thresholds allows us to check whether mild changes in many individuals or dramatic changes in some individuals drive the result. We apply the three cut-offs to the three different GHQ scale. A comparison of the different columns in Table 5 indicates that the point estimate of the effect of unemployment is larger and more significant for low and medium cut-offs. As a result, we conclude that unemployed individuals are likely to suffer moderate rather than severe increases in mental disorders.

\subsection{Robustness}

We now present a series of robustness checks for our main results. First, we use alternative definitions of the cells we introduced in Table 3. Our first alternative uses a finer distinction by age ( $c=\{$ under 30 , over 50 , province, male $\}$ ) and run the same regressions as in Table 4. Note that we now have 306 cells and control for many more cell fixed effects. Results are reported in Table 6 and are generally unaffected by this change. If anything, the results from the GHQ survey strengthen. We then add college education as an additional dimension ( $c=\{$ under 40 , province, male, college $\}$ and, again, control for cell fixed effects at this level (408 cells). Under this alternative definition, the results are also not 


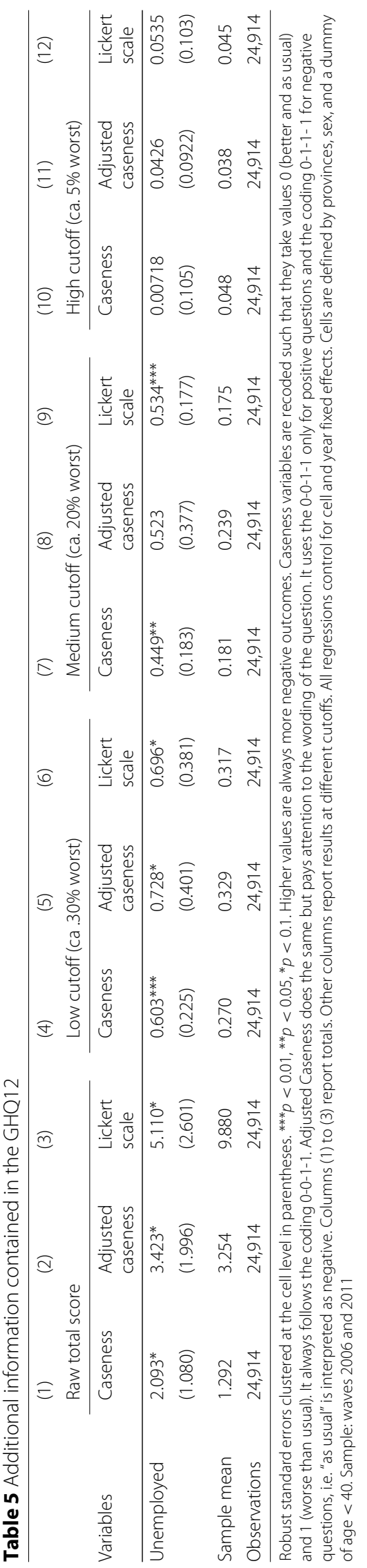




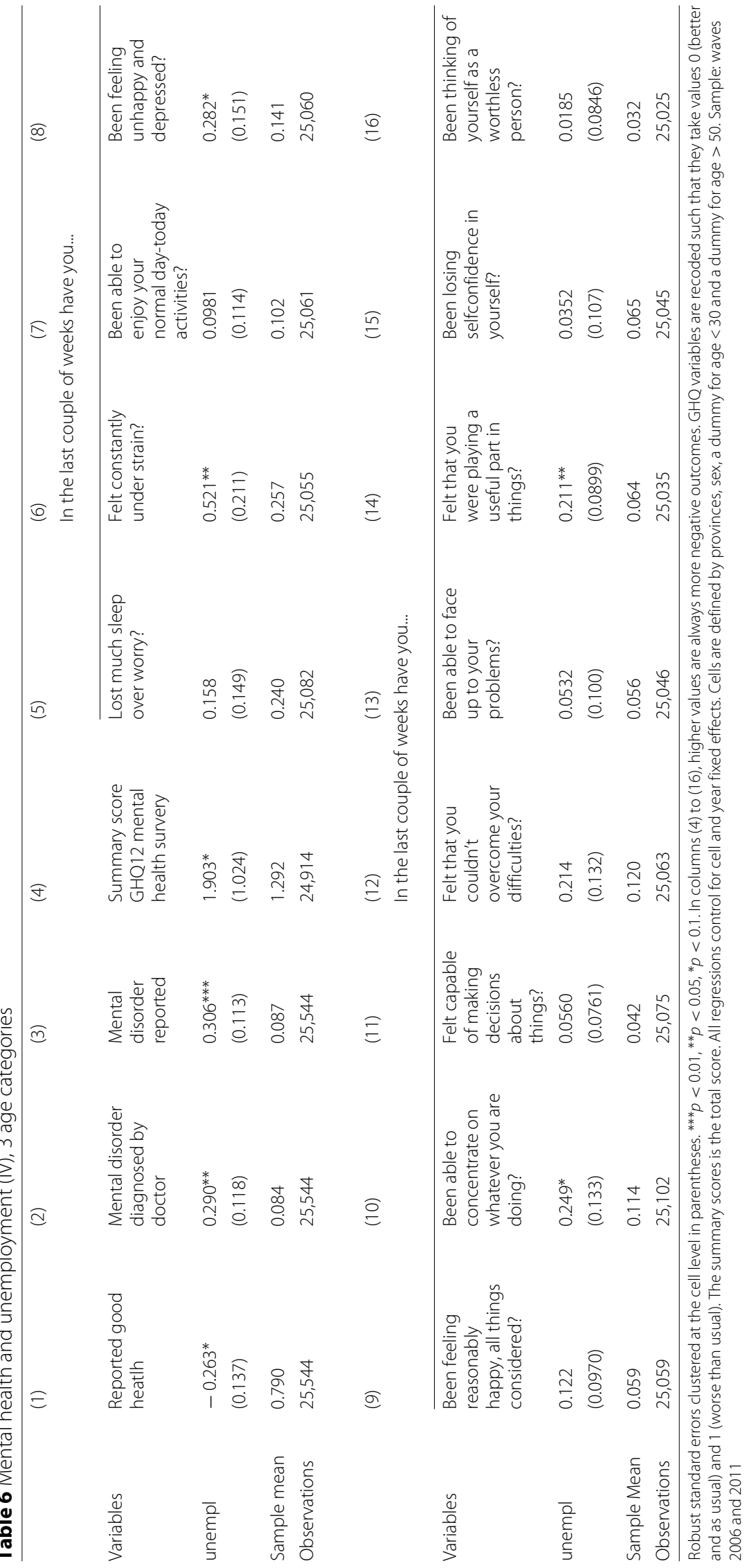


significantly affected (see Table 7). The coefficient on the general health indicator drops and becomes insignificant while several variables in the GHQ are now estimated with more precision. Overall our results are remarkably robust to the variations in cells. This suggests that our way of constructing cells is not crucial for the results we find.

Further, Table 8 presents a number of additional robustness checks. Column (1) uses employment growth in the previous three years to instrument for unemployment. Results remain unchanged. This is also true if we just use employment levels or employment changes. We also tried using total employment and again our results are robust. ${ }^{31}$ Column (2) uses only variation at the province level, clustering also only at this level. We still find a positive coefficient but the standard errors are now much larger, and the coefficient becomes insignificant. This suggests that within-province variation is the main driver of our results. Column (3) uses the unemployment rate at the cell level constructed from the Spanish Labor Force Survey instead of individual employment. Our results are robust to this different way of looking at the data. In column (4), we add the inactive population (pensioners, students, individuals working from home) and our results on unemployment do not change.

The, perhaps, most important robustness checks of our results are in columns (6) to (8). Here, we add province/year fixed effects to our main specification. This means we identify the effect of unemployment entirely from within-province variation so that changes in local availability of credit, social stigma, public sector spending, etc., which are only changing at the province level are controlled for. Our results are robust to this and even strengthen slightly. This is also true for all other measures of mental health presented in Table 4. In column (7), we add the waves 2001 and 2003. Unfortunately, the questions regarding mental disorder were not the same between 2001/2003 and 2006/2011 so that we need to switch to the more generic question of overall good health. The coefficient is very similar to the one in our main table (Table 4, column (1)). In column (8), we include a time trend for men. This is based on the idea that our construction sector instrument could be capturing the relative movement of mental health between men and women. Our results strengthen under this alternative specification, suggesting that the construction sector instrument does not merely capture long term gender trends. Our findings can only be explained by the fact that self-reported health first improved in cells which were close to the construction sector and then deteriorated. The relative peak in health was reached in 2006-at a time when unemployment in these cells was lowest.

Finally, we assess whether changes in aggregate unemployment may have a direct effect on workers' health beyond the direct effect of individual unemployment. Indeed, both employed and unemployed workers may suffer from seeing a general worsening of labor market conditions around them. We have already partially addressed this concern in the last specifications discussed in Table 8 (columns (6) to (8)) through the inclusion of province-year fixed effects which absorb any time-varying factor affecting mental health at the provincial level. We now focus on a narrower definition of labor market, namely the cell. Note that if cell-level unemployment affects individual health, not including this variable in the specification would potentially bias our IV results as the instrument (i.e., predicted cell employment in construction) would now be correlated with a relevant omitted variable (i.e., cell unemployment) left in the error term. We can directly check the plausibility of this concern by estimating OLS regressions of our main outcome variables on both individual and cell unemployment. Results are reported in Additional file 1: 


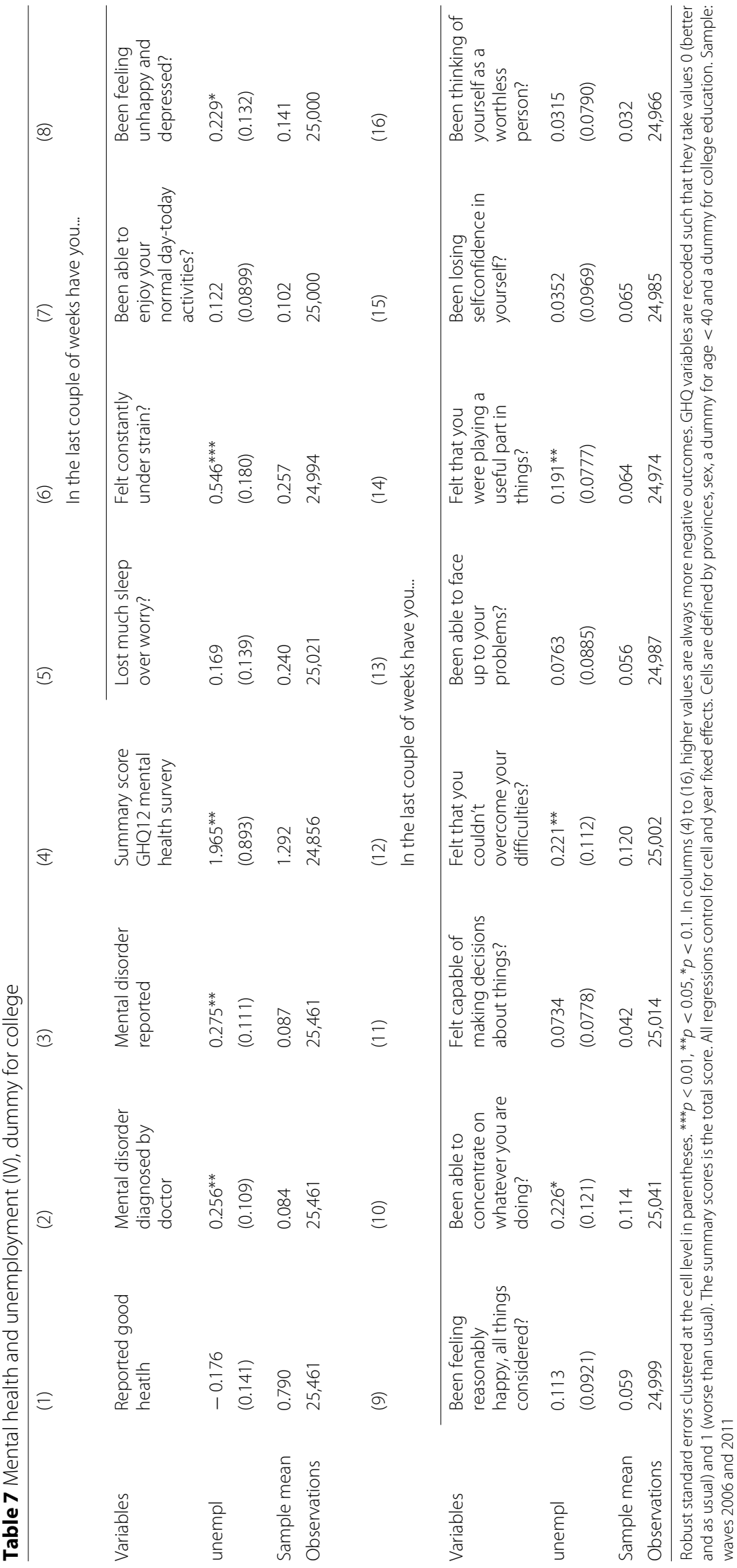


Table 8 Robustness

\begin{tabular}{|c|c|c|c|c|c|c|c|}
\hline & (1) & $(2)$ & (3) & (4) & $(6)$ & (7) & (8) \\
\hline & $\begin{array}{l}\text { Growth in last } \\
\text { three years as } \\
\text { IV }\end{array}$ & $\begin{array}{l}\text { Construction } \\
\text { employment } \\
\text { at province } \\
\text { level as IV }\end{array}$ & $\begin{array}{l}\text { Average } \\
\text { unemploy- } \\
\text { ment at cell } \\
\text { level }\end{array}$ & $\begin{array}{l}\text { Including } \\
\text { inactive } \\
\text { popula- } \\
\text { tion }\end{array}$ & $\begin{array}{l}\text { Province/year } \\
\text { fixed effects }\end{array}$ & $\begin{array}{l}\text { Including } \\
\text { early } \\
\text { waves }\end{array}$ & $\begin{array}{l}\text { Including } \\
\text { early waves } \\
\text { and male } \\
\text { time trend }\end{array}$ \\
\hline Variables & \multicolumn{5}{|c|}{ mental disorder diagnosed by doctor } & \multicolumn{2}{|c|}{ reported good health } \\
\hline Unemployed & $0.306^{* *}$ & 0.115 & $0.522^{* *}$ & $0.316^{* *}$ & $0.365^{* * *}$ & $-0.283^{* *}$ & $-0.606^{* * *}$ \\
\hline$(0.138)$ & $(0.408)$ & $(0.217)$ & $(0.159)$ & $(0.132)$ & $(0.125)$ & $(0.156)$ & \\
\hline Cell fixed effects & Yes & No & Yes & Yes & Yes & Yes & Yes \\
\hline Year fixed effects & Yes & No & Yes & Yes & No & No & No \\
\hline $\begin{array}{l}\text { Province/yearfixed } \\
\text { effects }\end{array}$ & No & No & No & No & Yes & Yes & Yes \\
\hline Observations & 25,544 & 25,544 & 25,544 & 36,563 & 25,544 & 46,330 & 46,330 \\
\hline
\end{tabular}

Table A4 (and are directly comparable with estimates reported in Table 2 and in the first column of Additional file 1: Table A3). Remarkably, the estimated coefficients on individual unemployment are unaffected by the inclusion of the cell unemployment rate, and this latter variable is not significantly correlated with individual health and mental health. This evidence-together with the estimates that condition on province-year fixed effects-supports the validity of our empirical strategy.

\subsection{Additional results}

Tables 9, 10, and 11 report additional results. In Table 9, we report IV estimates of the effects of unemployment on other health outcomes. We find some weak evidence that chronic headaches become more likely as a result of becoming unemployed, but otherwise, we find very few consistent results. This is interesting as it suggests that unemployment caused by the shock did not, yet, lead to a general deterioration of health. For example, the fact that the OLS results in Table 2 regarding stroke go away suggests that these were probably driven by reverse causality. In column (5) of Table 9, we show that the unemployed are more likely to take medicines. This is in line with the finding that general health-and in particular mental health-deteriorates.

Next, we turn to the opinion polls collected by the CIS in several years and test our identification strategy at the cell level with an entirely different data set. The CIS conducts

Table 9 Other health outcomes

\begin{tabular}{llllll}
\hline Variables & $(1)$ & $(2)$ & $(3)$ & $(4)$ & $(5)$ \\
& $\begin{array}{l}\text { Chronic } \\
\text { backpain } \\
\text { diagnosed by } \\
\text { doctor }\end{array}$ & $\begin{array}{l}\text { Chronic } \\
\text { headache } \\
\text { diagnosed by } \\
\text { doctor }\end{array}$ & $\begin{array}{l}\text { Heart disease } \\
\text { diagnosed by } \\
\text { doctor }\end{array}$ & $\begin{array}{l}\text { Stroke } \\
\text { diagnosed by } \\
\text { doctor }\end{array}$ & Takes medicines \\
\hline Unemployed & 0.275 & $0.254^{*}$ & 0.0863 & -0.00993 & $0.500^{* *}$ \\
& $(0.230)$ & $(0.147)$ & $(0.0530)$ & $(0.0191)$ & $(0.233)$ \\
Sample mean & 0.236 & 0.107 & 0.036 & 0.006 & 0.578 \\
Observations & 25,544 & 25,544 & 25,544 & 25,544 & 25,544 \\
\hline Robutstan
\end{tabular}

Robust standard errors clustered at the cell level in parentheses. ${ }^{* *} p<0.01,{ }^{* *} p<0.05,{ }^{*} p<0.1$. All regressions control for cell and year fixed effects. Cells are defined by provinces, sex and a dummy of age < 40. Sample: waves 2006 and 2011 
Table 10 Reduced form relationship between happiness, unemployment and exposure

\begin{tabular}{|c|c|c|c|c|}
\hline \multirow[b]{3}{*}{ Variables } & (1) & $(2)$ & \multirow{3}{*}{$\begin{array}{l}\text { (3) } \\
\text { NHS data } \\
\text { Reported good health }\end{array}$} & \multirow{3}{*}{$\begin{array}{l}\text { (4) } \\
\text { CIS data } \\
\text { Happy }\end{array}$} \\
\hline & NHS data & CIS data & & \\
\hline & \multicolumn{2}{|c|}{ Unemployed } & & \\
\hline \multirow[t]{2}{*}{ Cell exposure * year 2011/2012 } & $0.475^{* * *}$ & $0.279^{*}$ & $-0.203^{* * *}$ & $-0.281^{* *}$ \\
\hline & $(0.0821)$ & $(0.152)$ & $(0.0683)$ & $(0.128)$ \\
\hline Cell exposure * year 2006/2008 & (omitted) & (omitted) & (omitted) & (omitted) \\
\hline \multirow[t]{2}{*}{ Cell exposure * year 2003} & 0.116 & 0.0497 & $-0.200^{* *}$ & 0.0463 \\
\hline & $(0.0819)$ & $(0.141)$ & $(0.0966)$ & $(0.142)$ \\
\hline \multirow[t]{2}{*}{ Cell exposure * year 2001/2000 } & $-0.246^{* *}$ & -0.0970 & -0.0549 & -0.0659 \\
\hline & $(0.0968)$ & $(0.132)$ & $(0.0889)$ & $(0.118)$ \\
\hline Cell fixed effects & yes & yes & yes & yes \\
\hline Year fixed effects & yes & yes & yes & yes \\
\hline Observations & 46,358 & 7,792 & 46,330 & 7,742 \\
\hline$R$-squared & 0.074 & 0.066 & 0.046 & 0.050 \\
\hline
\end{tabular}

Robust standard errors clustered at the cell level in parentheses. ${ }^{* *} p<0.01,{ }^{* *} p<0.05,{ }^{*} p<0.1$. "cell exposure" is the average employment in construction in the cell in the year 2000. Samples are the years 2000, 2003, 2008, and to 2012 for the CIS data and 2001, 2003, 2006, and 2011 for the NHS data. All regressions use cells defined by provinces, sex, and a dummy for age $<40$

surveys to gather individuals' opinions on several issues (migration, politics, inequality, etc.). For some years and surveys, there are questions on the happiness of the respondent. In 2012 and 2003, the special module on "Family and Gender" contains the question: "All things considered, how satisfied are you with your life?", with the possible answers being: completely happy, very happy, quite happy, neither happy nor unhappy, quite unhappy, very unhappy, completely unhappy. In 2008, a special survey on "Religious beliefs" and in 2000 the module on "Life conditions" also include the question on individual happiness, with the possible answers being: very happy, quite happy, neither happy nor unhappy, quite unhappy, very unhappy. We merge the four different surveys and obtain a homogenous time series for individual happiness by constructing an indicator variable that takes value 1 in 2012 and 2003 if the individual reports being completely happy/very happy or quite happy with life and 0 otherwise. This indicator takes values 1 in 2008 or 2000 if the individual answer is very happy or quite happy. Using the four years, we collect information on 7719 individuals. We restrict the sample to respondents older than 16 and

Table 11 Unemployment and suicides (IV)

\begin{tabular}{llllll}
\hline Variables & $(1)$ & $(2)$ & $\begin{array}{c}(3) \\
\text { In(suicides) }\end{array}$ & $(4)$ \\
\hline Unemployment rate & -0.303 & $4.231^{* *}$ & $4.706^{* *}$ & $4.979^{* *}$ & $3.846^{* *}$ \\
& $(0.808)$ & $(1.981)$ & $(2.008)$ & $(2.122)$ & $(1.624)$ \\
Cell fixed effects & yes & yes & yes & yes & yes \\
Year fixed effects & yes & yes & yes & yes & yes \\
Control of In(population) & no & no & yes & yes & yes \\
Province time trend & no & no & no & yes & no \\
Survey years & $2001-2011$ & $2007-2011$ & $2007-2011$ & $2007-2011$ & $2007-2011$ \\
Observations & 2,035 & 921 & 921 & 921 & 1,283 \\
R-squared & 0.944 & 0.950 & 0.952 & 0.958 & 0.939 \\
\hline Robust standar & & & & &
\end{tabular}

Robust standard errors in parentheses. ${ }^{* *} p<0.01,{ }^{* *} p<0.05,{ }^{*} p<0.1$. Unemployment rate is the unemployment rate at the cell level. Column (1) uses data from 2001 to 2011. All other columns use data from 2007 to 2011. Columns (1) to (4) use cells defined by provinces, sex and a dummy of age $<40$. Column (5) uses two age dummies $<30,>50$ 
younger than 65 . In this sample, $87 \%$ of the respondents report to be happy according to our previous definition.

In Table 10, we use the CIS data and the longer time periods available in the general health question in the NHS to show that, compared to the boom years, the exposed cells experienced a dramatic decline in health and well-being in the crisis. We do this by forming interaction terms between the respective year of the survey and our exposure measure at the cell level, $s_{c, c o n s t r, 2000}$. We then omit the year right before the crisis so that the post-crisis dummy interacted with $s_{c, \text { constr,2000 }}$ captures the differential change in the lefthand-side variable in the exposed cells during the crisis compared to the years before the crisis. Columns (1) and (2) of Table 10 show that unemployment increased significantly in exposed cells in the crisis years when compared to the pre-crisis boom years. Columns (3) and (4) show that these economic declines were closely traced by falls in reported overall health and happiness in exposed cells. ${ }^{32}$ According to these estimates, reported good health would fall by $20 \%$ in fully exposed cells and reported happiness would even fall by $28 \%$. It is therefore unsurprising that, when we analyze the impact of unemployment on happiness with the CIS data using our instrument, we get large point estimates. ${ }^{33}$ These results provide additional evidence on the dramatic change experienced by the exposed population and lend some additional credibility to the size of IV effects we find in our main results.

Finally, we analyze the effect of unemployment on suicides. Figure 6 reports the level of suicides per 100,000 population which we calculate from deaths and population numbers. Suicide rates were falling from 7.6 in 2000 to 6.6 (per 100,000) in 2011. However, the fall is not uniform but interrupted by two large waves. The second wave starts exactly in 2007. In Table 11 we confirm that the increase in suicides during this second period took place in those cells that were hardest hit by unemployment. To do this we take unemployment rates at the cell level and run a IV regression of $\ln$ (suicides) on cell unemployment.

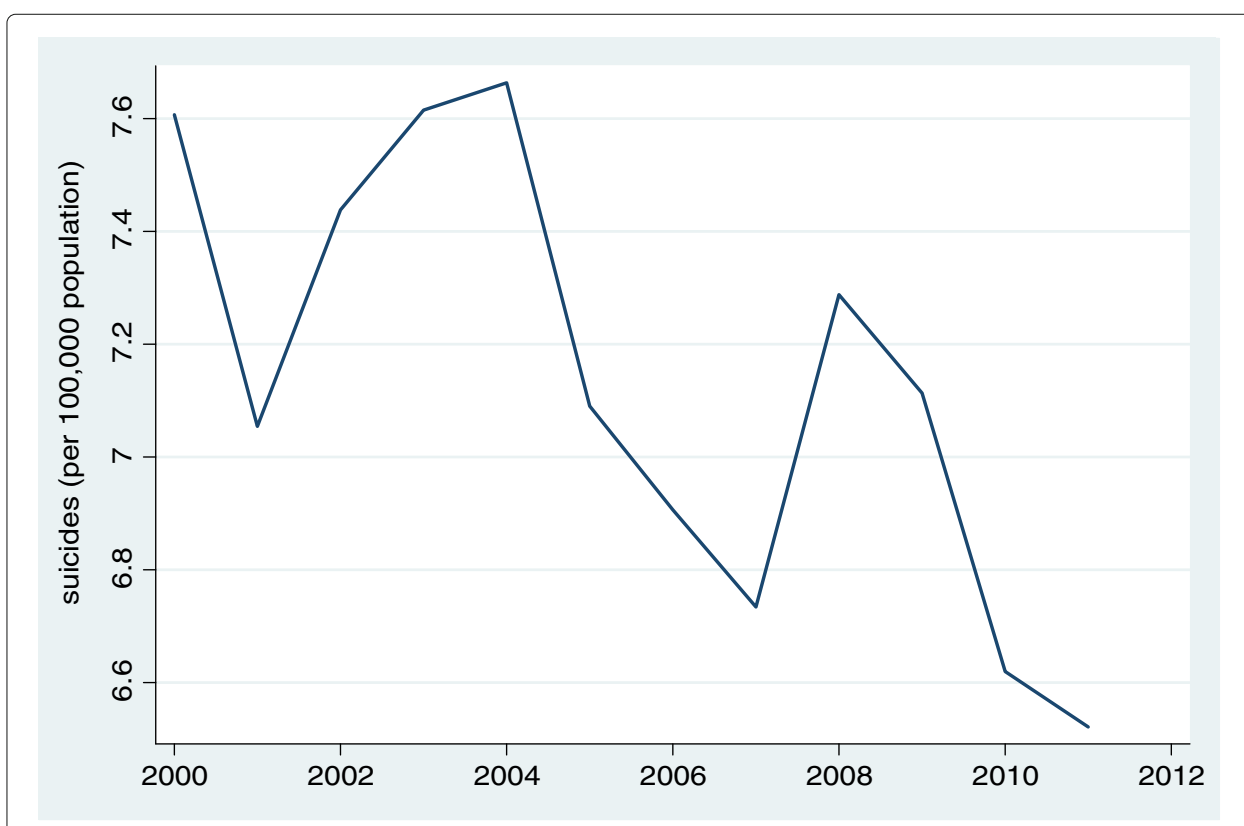

Fig. 6 Number of suicides in Spain. Source: Spanish Statistical Office. Death reports 
The only difference with respect to our main results is that we use unemployment rates from the EPA and therefore have yearly data for the period 2001-2011. Column (1) indicates that, overall, there is no consistent relationship between unemployment and suicides in the period 2001-2011. The positive association between unemployment and suicides only becomes apparent if we focus on the years after 2006. The relationship is then robust to the inclusion of $\ln$ (population) as a control, province time trends and modifications in the definition of cells. This result would suggest that an increase of the unemployment rate by 10 percentage points leads to an increase in suicides by about 45 percent. This is an increase of about 3 deaths in 100,000 population per year. However, this interpretation is problematic given the earlier peak which fell into a period of falling unemployment.

\section{Conclusions}

In this article, we analyze the relationship between unemployment and mental health in the context of the severe economic crisis in Spain. We exploit the extreme circumstances experienced by construction workers in the Spanish labor market to identify the causal effect of unemployment on health. We argue that job destruction as a result of the burst of the housing bubble represented an exogenous shock to labor demand that affected both the probability of being laid off as well as that of re-employment. Accordingly, our instrumental variable approach is able to estimate the causal effect of unemployment on health net of workers' selection in and out of unemployment. The IV estimates suggest that an increase of the unemployment rate by 10 percentage points due to the breakdown in construction raised self-reported poor health and mental disorders by about 3 percentage points. This is almost 15 percent of the sample mean for poor health and approximately 33 percent for mental disorders. We argue that the large magnitude of this effect responds to the fact that identification comes from a group of workers that were unable to escape unemployment after the collapse of the construction sector.

Our paper highlights a channel through which the collapse of an economic sector can affect the chances for a recovery of the labor market. Our findings raise the concern that a significant share of the Spanish labor force has been trapped in a cycle of skill mismatch and mental disorder. The share of long-term unemployment in total unemployment in Spain still stood at around 50 percent in 2016. The finding that this group was not only suffering from an income loss but from a loss of (mental) health is worrying on its own right. In addition, the combination of skill mismatch and the inability to search and embrace new labor market opportunities in such a large part of the population is a liability for the Spanish economy as a whole.

The cell-level analysis we provide has the weakness that we cannot control for individual fixed effects. However, we believe that our cell-level findings can nonetheless provide important insights. We have argued that treatment effects of unemployment duration could be themselves a function of the broader labor market context. In particular, it is possible to find negligible health effects of unemployment losses in "normal times" and large and persistent effects after sharp economic declines. In this way our results provide a possible explanation for labor market hysteresis following big declines.

This hysteresis channel will then also contribute to the fact that, as discussed by Blanchard (2018), the share of long-term unemployment in total unemployment increases with the unemployment rate and to the convex relationship between 
long-term unemployment and the unemployment rate. In normal times, with relatively low unemployment rates, workers' mental health may suffer less from unemployment spells that are likely to be short-lived. In situations of high unemployment, after a major economic shock such as the one we study, mental health may decline more dramatically and the unemployed get caught in a vicious cycle.

\section{Endnotes}

${ }^{1}$ See Figure A1 in the Additional file 2.

${ }^{2}$ Some authors, however, have questioned the assumption that plant closure is unrelated to workers' pre-dismissal observable and unobservable characteristics (Black et al. 2015; Hilger 2016).

${ }^{3}$ Black et al. (2015) also investigate whether the effect is stronger in higher unemployment areas. They fail to find statistically significant differences and argue that the lack of differential effect is probably due to the low average unemployment rate (3\%) in Norway over the period they study.

${ }^{4}$ See Goldsmith-Pinkham et al. (2018) for a recent survey and discussion of the use of Bartik instruments in empirical papers.

${ }^{5}$ The relationship between unemployment and health in the Spanish context has also been studied by Urbanos-Garrido and Lopez-Valcarcel (2015). They address a related but different empirical question with respect to ours: whether the self-reported gap in health between employed and unemployed workers increased during the recession. Their empirical strategy relies on matching employed and unemployed workers on individual characteristics (age, gender, education and region residence). This is similar to the first part of our analysis which uses OLS with cell fixed effects. However, this does not take care of reverse causality and unobserved variables seriously threatening identification. In the attempt of improving on this aspect, the authors match employed and unemployed individuals also on some health outcomes (i.e. suffering from chronic diseases). However, this has the problem of the inclusion of an endogenous outcome among the matching variables.

${ }^{6}$ See Krueger et al. (2014), Abraham et al. (2016) and Yagan (2017) for a discussion and evidence.

${ }^{7}$ It is important to note that this is not a contradiction to findings in Abraham et al. (2016) who show that those hit by job losses are as likely to get stuck in unemployment as those who are unemployed for other reasons. Our results suggest that a key distinction is whether job loss is driven by a large or a small shock.

${ }^{8}$ The question regarding general health status is the same in all four waves ("Over the last 12 months, would you say your health has been ... ? Very good, Good, Average, Poor or Very poor") while the other changed over time. The question on diagnosed mental disorders, for instance, had a version in 2001-2003 ("Are you currently diagnosed by your doctor with chronic depression, anxiety or any other mental disorder?") and a different one in 2006-2011 ("Have you ever been diagnosed by your doctor with chronic depression, anxiety or any other mental disorder?"), leading to considerable changes in mean answers.

${ }^{9}$ This is in line with data on death rates. Death rates from the four main sicknesses (cancer, respiratory diseases, infectious diseases and cardiovascular diseases) were falling throughout the 2000s including the crisis years - see Additional file 2: Figure A2. Data on death rates were taken from the population census between 2006 and 2011. 
${ }^{10}$ There are some concerns about the ability of the GHQ questionnaire to accurately measure mental health. However, we follow a large body of work which validates the measures with alternative, more direct, indicators of mental health status. The conclusion is that the GHQ is surprisingly good in many contexts in picking up mental disorders (De Jesus Mari and Williams 1985, Lobo et al. 1986 and Goldberg et al. 1997).

${ }^{11}$ See Additional file 1: Table A2 and Additional file 2: Figure A3 for further details on the GHQ scores.

12 Using the reported answers, we create an indicator variable that takes value 1 if indiviuals report to be completly satisfied/very satisfied/quite satisfied with their lives and 0 otherwise. The happiness indicators has mean 0.871 (and SD 0.335) over the period under analysis.

13 The same results hold if we include earlier waves.

${ }^{14}$ In the robustness checks (see Section 7.3), we use alternative definitions of cells that distinguish also by education level of the workers.

${ }^{15}$ In the paper, we estimate the effect of unemployment on eight main health and mental health outcomes, six of which are reported in Table 2 (reported good health; mental disorder diagnosed by doctor; chronic backpain diagnosed by doctor; chronic headache diagnosed by doctor; heart disease diagnosed by doctor; stroke diagnosed by doctor) and two in Table 4 (reported mental disorder; summary score of GHQ12). If we implement the most conservative adjustment for multiple hypothesis testing, namely the Bonferroni correction (setting the significance cut-offs at $\alpha / N$ with $N=8$ ), the effects we estimate with OLS on our four main outcomes of interest (reported good health; mental disorder diagnosed by doctor; reported mental disorder; summary score of GHQ12) are still strongly significant.

${ }^{16}$ A derivation in a dynamic framework is available from the authors by request.

${ }^{17}$ For simplicity, we remove the geographic dimension in this discussion.

${ }^{18}$ Several factors determine the impact of unemployment on each individual. For example, workers who can rely on savings, family wealth or spouse's income will not have to immediately worry about the economic consequences that losing a job implies. Beyond short-term concerns generated by income losses, the magnitude of the mental impact of unemployment will also depend, for instance, on individual psychological traits such as self-esteem and self-confidence, on whether the individual experienced unemployment before, on the social stigma that the individual attaches to the unemployment status, etc. Further, expectations should also play a role. Being laid off may be more distressing if the event was unexpected and/or if the individual deems it difficult to find a new job in the near future. A recent empirical literature has indeed shown that there is substantial heterogeneity in the level of unhappiness felt as a consequence of becoming unemployed (Winkelmann 2014), emphasizing the role played by, for instance, social norms (Stutzer and Lalive 2004) and religion (van Hoorn and Maseland 2013) in explaining this variation.

${ }^{19}$ This conjecture finds support in the existing evidence. For instance, Clark (2003) for the UK between 1991 and 1998 and Gielgen and van Ours (2014) for Germany between 1994 and 2007 document that workers who experience a substantial drop in well-being when entering unemployment exert a larger effort in searching for a job. However, the two studies reach different conclusions regarding the relationship between well-being deterioration and exiting rates from unemployment. This may be due to differences in the rate of arrival of vacancies in different time periods and countries. 
${ }^{20}$ Recall that we expect $\alpha^{A T E}$ to be negative.

${ }^{21}$ If instead workers who suffer the most for unemployment are more likely to be unemployed both terms would be negative.

${ }^{22}$ As documented in Section 3, the collapse of the construction sector in Spain led to both a large increase in unemployment and to a dramatic increase in its duration, with exit rates from unemployment being driven close to zero.

${ }^{23}$ See Additional file 2: Figure A1.

${ }^{24}$ See Fig. $4 \mathrm{~b}$ for the evolution of unemployment duration in the construction sector over the period.

${ }^{25}$ We employ the information in the second quarter of the EPA to merge it with that at the annual level in the NHS.

${ }^{26}$ The ten industries are: i) agriculture, fishing and mining; ii) manufacturing: food industry; iii) manufacturing: chemical industry; iv) manufacturing: other; v) construction; vi) services; vii) transport; viii) finance and real estate; ix) public administration, education and health; $x$ ) other: care services, entertainment, etc...

${ }^{27}$ In Additional file 2: Figure A4 we report kernel densities of the fitted values in column (6).

${ }^{28}$ In unreported regressions, we confirmed that, using OLS, longer duration correlates with worse reported mental health.

${ }^{29}$ OLS estimates for total GHQ score and for its individual items are reported in Additional file 1: Table A3.

${ }^{30}$ According to the Caseness scale the response to each of the 12 items in the GHQ are recorded such that they take value 0 if the answer is as usual or better than usual, and 1 if it is worse or much worse than usual. See Section 4.

${ }^{31}$ Results can be provided upon request.

${ }^{32}$ Additional file 2: Figure A5 displays a visual representation of Table 10, column (4).

${ }^{33}$ See Additional file 1: Table A5.

\section{Additional files}

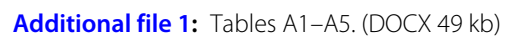

Acknowledgements

We are grateful to Ines Black for excellent research assistance. We thank seminar participants at the University of Duisburg, ESPE Conference 2016 in Berlin, IZA Workshop on Social and Welfare Consequences of Unemployment in Bonn and Health Economics Workshop in Alicante for useful comments and suggestions and David Card for comments on an earlier draft. We acknowledge financial support from the RecerCaixa programme 2012. Mueller acknowledges financial support Spanish Ministry of Economy and Competitiveness, through the Severo Ochoa Programme for Centres of Excellence in R\&D. Farr'e acknowledges the financial support of the Government of Catalonia (grant SGR2017-644) and the Spanish Ministry of Science (grant ECO2016-76866-R). All errors are ours. We would also like to thank the three anonymous referees and the editor for the useful remarks.

Responsible editor: Joni Hersch

Funding

We acknowledge financial support from the RecerCaixa programme 2012. The funds allowed the collection of data. It also financed a research assistant to clean the data and conduct the preliminary analysis.

Hannes Mueller acknowledges financial support from the Ramon y Cajal programme and Spanish Ministry of Economy and Competitiveness, through the Severo Ochoa Programme for Centres of Excellence in R\&D (SEV-2011-0075). Farré acknowledges the financial support of the Government of Catalonia (grant SGR2014-325) and the Spanish Ministry of Science (grant ECO2014-59959-P). These funds were used to finance the researchers to conduct the data analysis and the writing of the manuscript. 
Availability of data and materials

The datasets analyzed during the current study are available in the Spanish National Health Survey and the Spanish Labor Force Survey. Links to data sets:

https://www.mscbs.gob.es/estadEstudios/estadisticas/encuestaNacional/ https://www.ine.es/prodyser/microdatos.htm

\section{Competing interests}

The IZA Journal of Labor Economics is committed to the IZA Guiding Principles of Research Integrity. The authors declares that they have observed these principles.

\section{Publisher's Note}

Springer Nature remains neutral with regard to jurisdictional claims in published maps and institutional affiliations.

\section{Author details}

${ }^{1}$ Universitat de Barcelona, IAE (CSIC), MOVE and IZA, Barcelona, Spain. ${ }^{2}$ Queen Mary University of London, CEPR and IZA, London, UK. ${ }^{3}$ IAE (CSIC), Barcelona GSE, CEPR and MOVE, Barcelona, Spain.

Received: 12 March 2018 Accepted: 15 August 2018

Published online: 27 September 2018

\section{References}

Abraham KG, Haltiwanger JC, Sandusky LK, Spletzer JR (2016) The Consequences of Long Term Unemployment: Evidence from Matched Employer-Employee Data. IZA Discussion Papers 10223. Institute for the Study of Labor (IZA)

Bartik TJ (1991) Who Benefits from State and Local Economic Development Policies?. W.E. Upjohn Institute for Employment Research, Kalamazoo, MI

Bentolila S, Jansen M, Jimenez G (2017) When Credit Dries Up: Job Losses in the Great Recession. J Eur Econ Assoc 16(3):650-695

Blanchard OJ (2018) Should We Reject the Natural Rate Hypothesis J Econ Perspect 32(1):97-120

Blanchard OJ, Katz LF (1992) Regional Evolutions. Brook Pap Econ Act 0:1:1-69

Black S, Devereux P, Salvanes K (2015) Losing Heart? The Effect of Job Displacement on Health. ILR Rev 68(4):833-861 Böckerman P, Ilmakunnas P (2009) Unemployment and self-assessed health: Evidence from Panel Data. Health Econ 18:161-179

Browning M, Moller Dano A, Heinesen E (2006) Job displacement and stress-related health outcomes. Health Econ 15(10):1061-1075. John Wiley \&amp; Sons, Ltd

Browning M, Heinesen E (2012) The effect of job loss due to plant closure on mortality and hospitalization. J Health Econ 31:599-616

Clark A (2003) Unemployment as a Social Norm: Psychological Evidence from Panel Data. J Labor Econ 21 (2):289-322

Clark A, Georgellis Y, Sanfey P (2001) Scarring: The Psychological Impact of Past Unemployment. Economica 68:221-241

Clark A, Oswald AJ (1994) Unhappiness and unemployment. Econ J 104(424):648-659

De Jesus Mari J, Williams P (1985) A comparison of the validity of two psychiatric screening questionnaires (GHQ-12 and SRQ-20) in Brazil, using Relative Operating Characteristic (ROC) analysis. Psychol Med 15(3):651-659

Di Tella R, MacCulloch RJ, Oswald AJ (2001) Preferences over inflation and unemployment: evidence from surveys of happiness. Am Econ Rev 91(1):335-341

Dooley D, Fielding J, Levi L (1996) Health and Unemployment. Annu Rev Public Health 17:449-65

Dustmann C, Fasani F (2016) The Effect of Local Area Crime on Mental Health. Econ J 126(593):978-1017

Eliason M, Storrie D (2006) Lasting or latent scars? Swedish evidence on the long-term effects of job displacement. Labor Econ 24(4):831-856

Eliason, M, Storrie D (2009a) Does job loss shorten life? J Hum Resour 44(2):277-302

Eliason M, Storrie D (2009b) Job Loss is Bad for your Health - Swedish Evidence on Cause-Specific Hopsitalization following Involuntary Job Loss. Soc Sci Med 68:1396-1406

Eliason, M, Storrie D (2010) Impatient psychiatric hospitalization following involuntary job loss. Int J Ment Health 39(2):32-55

Erikson EH (1959) Identity and the Life Cycle. Psychol Issues 1(1):50-100

García-Gómez P, Jones AM, Rice N (2010) Health effects on labor market exits and entries. Labor Econ 17:62-76

Gielen A, Van Ours J (2014) Unhappiness and Job Finding. Economica 81:544-565

Goldberg DP (1972) The Detection of Psychiatric Illness by Questionnaire. Oxford University Press, Oxford

Goldberg DP, Gater R, Sartorius N, Ustun TB, Piccinelli M, Gureje O, Rutter C (1997) The validity of two versions of the GHQ in the WHO study of mental illness in general health care. Psychol Med 27(1):191-197

Goldberg DP, Oldehinkel T, Ormel J (1998) Why GHQ threshold varies from one place to another. Psychol Med 28:915-921

Goldsmith AH, Veum JR, Darity W (1996) The impact of labor force history on self-esteem and its component parts, anxiety, alienation and depression. J Econ Psychol 17(2):183-220

Goldsmith-Pinkham P, Sorkin I, Swift H (2018) Bartik Instruments: What, When, Why, and How. NBER Working Papers 24408. National Bureau of Economic Research, Inc.

Goodchild ME, Duncan-Jones P (1985) Chronicity and the General Health Questionnaire. Br J Psychiatr 146:55-61

Hilger NG (2016) Parental Job Loss and Children's Long-Term Outcomes: Evidence from 7 Million Fathers' Layoffs. Am Econ J Appl Econ 8(3):247-83

Hill JMM (1977) The Social and Psychological Impact of Unemployment: A Pilot Study. Tavistock, London

ILO (2014) Spain: Growth with jobs. International Labor Organization

Jackson P, Warr P (1984) Unemployment and III-Health: The Moderating Role of Duration and Age. Psychol Med 14:605-614

Jacobson L, LaLonde R, Sullivan D (1993) Earnings losses of displaced workers. Am Econ Rev 83(4):685-709 
Jahoda M (1982) Employment and Unemployment: A Social-Psychological Analysis. Cambridge University Press, New York KasI SV, Jones BA (2000) The impact of job loss and retirement on health. In: Berkman LF, Kawachi I (eds). Social Epidemiology. Oxford University Press, Oxford. pp 118-136

Kessler R, Turner J, House J (1987) Intervening Processes in the Relationship between Unemployment and Health. Psychol Med 17:949-61

Kuhn A, Lalive R, Zweimüller J (2009) The public health costs of job loss. J Health Econ 28:1099-1115

Krueger AB, Mueller A (2011) Job Search, Emotional well-being and Job Finding in a Period of Mass Unemployment: Evidence from High-Frequency Longitudinal Data. Brookings Papers on Economic Activity, Economic Studies Program, The Brookings Institution 42(1 (Spring)):1-81

Krueger AB, Cramer J, Cho D (2014) Are the Long-Term Unemployed on the Margins of the Labor Market? Brookings Papers on Economic Activity, Economic Studies Program, The Brookings Institution 45(1 (Spring)):229-299

Lobo A, Pérez-Echeverría MJ, Artal J (1986) Validity of the scaled version of the General Health Questionnaire (GHQ-28) in a Spanish population. Psychol Med 16(1):135-140

McKee-Ryan FM, Song Z, Wanberg CR, Kinicki AJ (2005) Psychological and physical well-being during unemployment: a meta-analytic study. J Appl Psychol 90(1):53-76

Miller D, Page M, Stevens A, Filipski M (2009) Why are recessions good for your health Am Econ Rev 99(2):122-127

Rege M, Telle K, Votruba M (2009) The effect of plant downsizing on disability pension utilization. J Eur Econ Assoc 7(4):754-785

Ruhm C (1991) Are workers permantely scarred by job displacements Am Econ Rev 81:319-323

Ruhm CJ (2000) Are Recessions Good for Your Health Q J Econ 115(2):617-50

Ruhm, CJ (2003) Good Times Make You Sick. J Health Econ 22(4):637-58

Ruhm CJ (2005) Mortality Increases During Economic Upturns. Int J Epidemiol 34(6):1206-11

Salm M (2009) Does job loss cause ill health Health Econ 18(9):1075-1089

Schaller J, Stevens AH (2015) Short-run effects of job loss on health conditions, health insurance, and health care utilization. J Health Econ 43:190-203

Seligman M (1975) Helplessness: On Depression, Development and Death. W. H. Freeman, San Francisco, CA

Stevens A, Miller D, Page M, Filipski M (2015) The best of times, the worst of times: understanding pro-cyclical mortality. Am Econ J Econ Policy 7(4):279-311

Stewart JM (2001) The impact of health status on the duration of unemployment spells and the implications for studies of the impact of unemployment on health status. J Health Econ 20(5):781-796

Stutzer A, Lalive R (2004) The role of social norms in job searching and subjective well-being. J Eur Econ Assoc 2(4):696-719

Sullivan D, von Watchter T (2009) Job Displacement and Mortality: An Analysis using Administrative Data. Q J Econ 124(3):1265-1306

Urbanos-Garrido RM, Lopez-Valcarcel BG (2015) The Influence of the Economic Crisis on the Association Between Unemployment and Health: An Empirical Analysis for Spain. Eur J Health Econ 16:175-184

van Hoorn A, Maseland R (2013) Does a Protestant work ethic exist? Evidence from the well-being effect of unemployment. J Econ Behav Organ 91(C):1-12

Warr P (1987) Work, Unemployment and Mental Health. Oxford University Press, Oxford

Warr P, Jackson P (1984) Men Without Jobs: Some Correlates of Age and Length of Unemployment. J Occup Psychol 57:77-85

Winkelmann L, Winkelmann R (1998) Why are the unemployed so unhappy? Evidence from panel data. Economica 65:1-15

Winkelmann R (2014) Unemployment and happiness, IZA World of Labor, Institute for the Study of Labor (IZA):1-94

Yagan D (2017) Employment Hysteresis from the Great Recession. NBER Working Papers 23844. National Bureau of Economic Research, Inc.

\section{Submit your manuscript to a SpringerOpen ${ }^{\circ}$ journal and benefit from:}

- Convenient online submission

- Rigorous peer review

- Open access: articles freely available online

- High visibility within the field

- Retaining the copyright to your article

Submit your next manuscript at $\gg$ springeropen.com 